\title{
SOME EXPERIMENTS ON PROTECTIVE COLORATION
}

\author{
R. T. YOUNG \\ University of North Dakota \\ EIGHT TEXT FIGURES AND THREE PLATES
}

The theory of protective and aggressive coloration, assuming as it does, the use of such color in protecting its possessors from their enemies, or enabling them to steal unnoticed on their prey, has, as yet, insufficient experimental evidence for its foundation, being based largely upon human experiences of taste, sight, and smell, which are by no means a fair criterion of similar senses in lower animals.

Beddard ('92) in his work on Animal Coloration says, page 156:

The instance shows the pitfalls which surround the path of those who wish to deduce theories from experiments of this kind, which are necessarily made in very great ignorance of bird psychology, or even physiology.

On page 166 of the same book he says:

These experiments certainly bring out the fact that the likes and dislikes of insect-eating animals are purely relative. They are further proof of the old saying that one man's meat is another man's poison. . . . But none of these experiments are thoroughly satisfactory. It is difficult to interpret them and they are often contradictory, for a bird will eat one day what it has refused before.

Again on page 196 he says:

It is not reasonable to lay much stress upon the fact of insects possessing qualities which are disagreeable to ourselves, for it by no means follows that these same qualities affect the enemies of the insects. Indeed, there is experimental evidence that the reverse is the case.

There are numerous other difficulties in experiments of this sort, first among which is the fact that they have mostly been

THE JOURNAL OF EXPERIMENTAL ZOÖLOGY, VOL. 20, NO. 4 
performed upon caged animals, and it is quite possible that confinement materially alters their senses. The space factor also enters into experiments with caged animals, by limiting the distance between them and their prey. I shall refer at greater length to these objections later on.

In addition to the experiments cited by Beddard (l.c.) and Poulton ('90), the most important work I know of is that of Finn ('98), Judd ('99), Pritchett ('03), and Reighard ('09), all dealing chiefly with warning color. Taken as a whole, these experiments are inconclusive, some of them supporting, others refuting, the theory. Their general tendency, however, has been to cast grave doubts upon it. There are a few isolated experiments on protective coloration proper, but they are too few to carry much weight and their results are also contradictory.

Among the criticisms of this theory is the objection that such coloration is not really protective, and that animals possessing it seek refuge in other ways, as in flight and hiding. Thus Werner ('07), sarcastically refers to a certain supporter of this theory as a 'Sonntagsjäger,' and cites evidence supposedly proving the inefficiency of color in protecting its possessors from their enemies.

To put the theory to an experimental test, I have carried out a series of 144 experiments during the past six years, using for the purpose crows, hawks, owls, domestic chickens, prairie chickens, grackles, kingbirds, and martins as preyers, and several kinds of mammals and insects as prey.

The photographs illustrating this article were taken on Cramer ischromatic plates through a ray filter,,${ }^{1,2}$ and printed on 'glossy Cyko' paper manufactured by the Ansco Company of Binghamton, New York.

Considerable difficulty attends a representation of color contrasts by photography, as the effect upon the photographic plate is not necessarily the same as upon the human retina. Very different effects may be obtained by manipulating either the exposure or the development of the plate, or both. I have

1 Ingento,' Series B, Burke and James, Chicago, Illinois.

2 Except figures 37, 50, and 52, in making which no filter was used. 
endeavored to neither increase or decrease the contrast in any case, but to reproduce as nearly as may be the effect as it appeared to my eye. If I have erred in any direction, it has been in minimizing the effect of the contrast and resemblance. In every case the camera was placed much nearer (from 0.2 to $3.0 \mathrm{~m}$.) the backgrounds than were the birds at the commencement of the experiments, ${ }^{3}$ thus diminishing the effect of the contrast and resemblance. With the exception of figures $8,11,12,13$, $17,18,21,22,23,49,50,51,52$, and 53 , the photographs were made with dry specimens. The color changes, if any, were not, however, great enough to be appreciable in the photographs.

Light and shade moreover in many instances altered the color effect. Thus in figures 25, 27, 41 to 43,46 the effect of the reflected light has been to make a dark insect (Gryllus, Silpha) appear light against a dark background. The same effect of course occurs in nature, so that the photographs are probably reasonably true to life in this respect.

\section{SERIES I}

Plate 1, figures 12,17 and 18

In the first series of these experiments, I employed two individuals of the common crow (Corvus americanus) and frogs (Rana cantabrigensis and Rana pipiens). The crows were kept in a cage $0.9 \times 0.9 \times 1.2 \mathrm{~m}$. in size, on the top of which was a perch $0.7 \mathrm{~m}$. from the floor. On this floor, I prepared two backgrounds, one of mud or fresh grass, the former of which harmonized very closely with the color of $R$. cantabrigensis and the latter with that of R. pipiens, and the other of dry sand, with which the color of the frogs made a decided contrast. Upon each of these backgrounds a frog was placed, rendered insensible by sharply tapping the skull. The crows soon learned to drop from the perch and seize the frogs, ${ }^{4}$ and a record was kept of the number of frogs taken from the mud and sand respectively, in the hope

${ }^{3}$ In many cases, as I shall explain later, the birds were close to the backgrounds at the time the experiments became effective.

${ }^{4}$ When first fed frogs, the crows appeared suspicious of them, but soon learned to eat them readily. 
of ascertaining whether or not the harmony of the frogs' color with that of their background was really protective to them. I at first designed to keep the crows confined in a closed compartment at the top of the cage in order to prevent their observing the placing of the frogs and the consequent fastening of their attention on one of them. I soon found that this proceeding was unnecessary, however, as the crows delayed for several minutes, in some cases more than half an hour, before dropping to seize their prey, and gave no evidence whatever of having their attention fixed on either of the frogs at the time these were placed upon the backgrounds. In some instances, the frogs would move after being placed in position, thus drawing the attention of the crows. Where this occurred, I have noted it in the account of the experiment. A further difficulty was experienced in the high wind to which the cage was at times exposed during the experiments, which blew the loose sand over the frogs, changing to a considerable extent their color, as well as that of the mud background. A third difficulty was the change of color which the frogs underwent after being stunned, and also after being removed from the dark box, in which they were kept, into the light. Thus their color, in addition to the individual differences, was not constant in all of the experiments. The sum total of these influences, while introducing uncertainty into the results, tended to diminish rather than to increase the protective influence of the frogs' color. Hence my results, tending to prove such influence under these disadvantageous conditions, should be at least accepted at par value, rather than discounted in consequence of such conditions.

Experiments 1 and 2. One specimen of cantabrigensis was placed on mud and one on sand in each experiment. In each the frogs were taken from the sand. In the second experiment the frog on the sand moved just as I left the cage, so that the crow's attention was possibly drawn to this frog rather than to the other. This is not probable however as the crow delayed seizing it for several minutes after I left. After seizing this frog, that on the mud background moved, and the crow dropping the first frog, seized the other one.

Experiment 3. One specimen of pipiens was placed on grass and one on sand. A few minutes later a crow dropped on to the grass, but took the frog from the sand. 
Experiment 4. One specimen of pipiens was placed on grass and one on sand. After more than half an hour, a crow dropped and picked the frog from the grass.

Experiment 5. One specimen of pipiens was placed on mud and one on sand. ${ }^{5}$ In a few minutes a crow dropped on the mud but took the frog from the sand.

Experiment 6 . One cantabrigensis was placed on sand and one on mud. ${ }^{6}$ After considerable delay, the frog was taken from the sand. In this experiment particularly it appeared very probable that the crow saw the frog before dropping to seize it, as it turned its head from side to side examining the floor of the cage before doing so.

Experiment 7. One cantabrigensis on mud and one on sand. ${ }^{6}$ The former was seized by a crow directly after dropping and with little inspection.

Experiment 8. One pipiens on sand and one on grass. Former taken.

Experiment 9. This was a repetition of Experiment 8 and the same results were obtained. The frog was seized by the crow directly on alighting.

Experiment 10. One pipiens on sand and one on grass. Former taken.

Experiment 11. Same as Experiment 10.

Experiment 12. One pipiens on grass and one on sand. Former taken. In this experiment the frog was apparently not seen until after the crow had alighted, as the latter started to walk to the opposite side of the cage and was very close to the frog on the grass before appearing to see it, when it stopped and seized it.

\section{Summary}

Thus in nine of these twelve experiments, or in 75 per cent, the frog was taken from that background with which it formed the better contrast, while in one of the remaining three, the difference in contrast between the two backgrounds was not marked. ${ }^{6}$

\section{SERIES II}

Plate 2, figures 99 and 41

In this series also a crow was employed as the preyer and crickets (Gryllus pennsylvanicus) as the prey. The crow was confined in a cage $5.0 \times 2.4 \times 1.5 \mathrm{~m}$. in size, at one end of which was a

${ }^{5}$ In this experiment the frogs died, changing color from green to dark olive after being stunned.

${ }^{6} \mathrm{~A}$ high wind was blowing during this experiment and the sand was driven over onto the mud and altered the color of the latter to a considerable extent. 
perch $0.3 \mathrm{~m}$. from the ground. At the opposite end backgrounds were prepared of sifted flour and coal dust mixed with pieces of anthracite coal. The crickets were arranged in similar positions on each background, the number used being indicated in every experiment. Care was taken in placing the crickets to avoid attracting the crow's attention to any of them, the experimenter placing himself between the perch and the background when arranging the experiments. The harmony between the color of the crickets and the coal background was very close, the dull color of the cricket's back and wings agreeing well with that of the coal dust, and the brilliant black of the legs and head of the cricket simulating closely the bits of coal scattered among the dust.

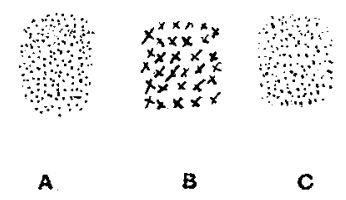

Fig. A $A$ and $C$-flour, $B$-coal.

Experiment 1. Four crickets were placed on flour and four on coal. In about one minute the crow dropped to the ground from its perch and went directly to the backgrounds taking a cricket from the flour.

Experiment 2. In this experiment, three crickets were placed on flour and three on coal. The results were similar to those of Experiment 1, except that two crickets were taken from the flour.

Experiment 3. Two crickets were placed on each background. The crow went immediately to the backgrounds, approached a little nearer to the coal than the flour, but took a cricket from the flour.

Experiment 4. In this and the following experiments, three backgrounds were prepared as shown in figure $\mathrm{A} ; A$ and $B$ being the same as those employed in the previous experiments, and $C$ a new one. Two erickets each were placed on $B$ and $C$. A minute later the crow dropped to the ground and passed directly to the backgrounds. After hesitating a moment, it took one cricket from $C$.

Experiment 5. Three crickets were placed on both $A$ and $C$ and six on $B$. The crow dropped from its perch to the floor on the side of the cage nearest $A$. It several times ran past all three backgrounds, and finally went to $B$ taking three crickets therefrom. The experiment lasted about nine minutes. 
Experiment 6. My notes regarding this experiment are not entirely clear in respect to the number of crickets. Either two or four (probably two) were placed on $A$ and $C$ and four on $B$. The erow twice dropped from its perch to the floor near the backgrounds, and returned to its perch. A third time it flew to the side of the cage nearest $A$, passed and repassed the three backgrounds and then returned to its perch. A fourth time it left its perch passing to the side of the cage near $A$, then to a point near $C$. It then returned to $A$ and took one cricket therefrom. Time of experiment six minutes.

Experiment \%. Same arrangement of background and prey as in Experiment 6 . The crow left its perch almost immediately, passed the backgrounds from side to side twice, and then took one cricket from $B$.

Experiment 8. Ten crickets were placed on both B and $C$. The crow left its perch, passed the backgrounds two or three times, and then took one cricket from $B$.

Experiment 9. Same arrangement of background and prey as in Experiment 8. The crow at once left its perch and passed to the side of cage nearest $A$. It then approached the backgrounds, retreated a step or two, approached again and took one cricket from $B$.

\section{Summary}

In this series the arrangement showing the greater contrast was chosen five out of nine times, or 55 per cent.

\section{SERIES III}

\section{Plate 2, figures 50 and 52}

Experiments with the Purple Martin (Progne subis) and grasshoppers (Melanoplus ${ }^{7}$ and Xyphidium fasciatum).

A pair of purple martins were taken from the nest just before learning to fly. They were kept in a cage $2.4 \times 2.4 \times 0.8$ $\mathrm{m}$. in size. At first the birds were very wild, refusing to eat unless forced to do so. They soon became tame enough to eat readily from the hand, however, but it was several days after their capture before they learned to feed themselves.

${ }^{7}$ I have not attempted to differentiate the spp. of Melanoplus used in this and succeeding series of experiments. Both M. atlantis and infantilis are common in the region and these are probably the two mostly used. The differences in color and markings between different species are so small as to be negligible for the purpose of these experiments. 
The experiments to be recorded were performed by arranging two backgrounds, one of straw and one of grass, ${ }^{8}$ on the floor of the cage, on each of which were placed in as nearly their normal position as possible five dead grasshoppers of each species. During the placing of the insects the birds were confined in a small box on the wall of the cage. After being released they seldom flew directly to the floor of the latter, usually alighting first on a perch placed about midway between the box and the floor. They would then drop to the floor and hop back and forth in search of food. They did not apparently espy the insects until coming close to them. The insects were occasionally tumbled over by the birds in alighting, walking, or flying over the backgrounds; thus in some cases bringing the ventral surface uppermost, and in others causing them to drop down between the blades of straw and grass, and changing the conditions of the experiment. I endeavored to obviate this difficulty by replacing the insects in position after each time that the birds fed from either background. As the birds were hungry, however, they would usually pick up several insects before I could drive them away, so that a certain amount of uncertainty is necessarily here involved. The reasonably consistent results of the experiment, however, render this uncertainty practically negligible.

The order of resemblance between the grasshoppers and the background, as it appeared to my eye, was as follows, giving those combinations first in which the resemblance was greatest: Xyphidium-grass, Xyphidium--straw, Melanoplus-grass, and Melanoplus-straw. The resemblance between Xyphidium and grass was. so great as in many cases to cause me great difficulty in finding the grasshoppers on this background a few moments after placing them, and with my eye at a distance of only about $30 \mathrm{~cm}$. above it. The fact that the martins did not approach the insects from above, but from the side, the bird's line of sight striking the body of the insect a little above the middle of the latter, necessitates the comparison of the lateral, rather than the dorsal color of the insect with that of the background in

${ }^{8}$ In Experiment 2 a single background consisting of a white sheet, and in 5 and 6 , backgrounds of mud and sand, instead of grass and straw, were employed. 
evaluating the results. In both cases, however, the lateral color is practically the same as the dorsal, while in that of Xyphidium the light straw colored wings folded over the back tended on both backgrounds to enhance the protective effect; for on the straw background they closely matched the color of the straw, and on the grass they gave the appearance of blades of dry grass lying among the green.

Experiment 1. The insects were placed on the backgrounds at 7.26 a.m., and the box opened. Previous to 7.45 a.m. the dead insects were not eaten, although the birds passed them several times in hopping about the floor of the cage, and one live and active specimen, which had been left in the cage by mistake, was taken from the grass. From 7.45 to 8.30 the birds were not observed. During this time two Melanoplus were taken from the straw and one from the grass. Between 8.30 and 8.45 the three Melanoplus remaining on the straw and two of the four on grass, and one of five Xyphidium ${ }^{9}$ on straw were taken. Twice during this period a bird passed by the grass without feeding. Summed up the result of this experiment is: 8 Melanoplus (5 from straw; 3 from grass), and 1 Xyphidium from straw (probably) eaten.

Some uncertainty was introduced in this experiment by the presence of active specimens in the cage, which, dropping upon the backgrounds among the dead insects, attracted the attention of the birds.

Experiment 2. In order to ascertain which species, if either, the martins preferred, I placed five of each on a white cloth where both kinds were plainly visible. If any difference in contrast existed, that between Melanoplus and the white cloth was the greater. One bird took five Xyphidium and one Melanoplus and would probably have eaten the remaining Melanoplus if I had not interrupted it at this point. They were eaten shortly after. This shows that for this individual at this time at least there was no preference for Melanoplus over Xyphidium.

Experiment $8 . \quad$ In this experiment one bird passed by the grass and picked a Melanoplus from the straw. Then a bird ${ }^{10}$ flew over both the grass and the straw and picked two Melanoplus from the latter. I now left three of each species on the straw and five of each on the

\footnotetext{
${ }^{9}$ Some uncertainty exists regarding this. At 8.45 there were five Xyphidium remaining on the grass. From its position, it is possible, though not probable, that one of these had been thrown from the straw to the grass by the movements of the birds, in which case the record would be one Xyphidium, from the grass and none from straw taken. It was of course impossible to watch the birds from a distance and keep individual specimens of the grasshoppers in view.

${ }^{10}$ The identity of each individual of the two birds I could not distinguish.
} 
grass. One bird now picked a Melanoplus from the grass and then passed to the straw and picked one of the same from the latter.

Two of each species were now left on the straw and four of each on the grass. A bird went first to the grass where a Melanoplus jumped directly before it and fell under a grass blade. The bird then passed to the straw and took one Melanoplus.

This experiment was not observed further for some time, when it was found that all of the insects had been eaten except three or four Xyphidium on the grass. ${ }^{\text {Il }}$ Summed up the results of this experiment are as follows: During the period of observation five ${ }^{12}$ Melanoplus were taken from the straw, and one from the grass. After this one Melanoplus and two Xyphidium were taken from the straw and four Melanoplus from the grass.

Experiment 4. In this experiment the position of the insects was reversed they being placed ventral side up. A yellow and dark gray surface in the case of Melanoplus, and a green and straw colored surface in that of Xyphidium was now exposed to the view of the birds. The order of resemblance to my eye in this case was as follows: Xyphidium-grass, Melanoplus--straw, and Xyphidium-straw, Melanoplus-grass (the two latter about equal). 1: One bird passed first to the straw and seized a Xyphidium. Four of each species were now left on the straw and five of each on the grass. A bird now passed to the straw first (from the side of cage nearest to the latter) and took a Melanoplus therefrom. Five of each species were now placed on straw and grass respectively. A bird passed to the straw (from the side nearest thereto) and took one Xyphidium and one Melanoplus. Four of each species were now placed on straw and five of each on grass. A bird flew over the straw to the grass and took a Melanoplus. Four of each species were now left on both straw and grass. A bird went to the straw and took one of each species. Three of each species were now left on straw and four of each on grass. One bird now passed to the straw and took two Xyphidium and one Melanoplus. The straw was now removed and five of each species were left on the grass. In three feedings from the grass four Melanoplus and no Xyphidium were taken, the number of each species being kept constant after each feeding.

Summation of the results of Experiment 4. Before removal of straw five Xyphidium and four Melanoplus were taken from it and

11 The exact number left on the grass untouched during this period I am not certain of, as they had all fallen more or less among the blades of grass and one of them may have been concealed by the grass from the first.

12 One of these was replaced making a total of six instead of five Melanoplus placed on straw during this experiment.

${ }^{13}$ It must be remembered in this, as in the preceding experiments, that the surface exposed to the birds' view from a position on the floor of the cage was somewhat different from that exposed to the view of an observer looking down onto the floor from above. 
one Melanoplus from the grass. After removal of straw four Melanoplus and no Xyphidium were taken from the grass.

A comparison of the results of this experiment with those of Experiments 1 and 3 shows a marked difference, due unquestionably to the change in position of the insects and the consequent change in color contrast. In Experiments 1 and 3 the Melanoplus - straw combination was the one mostly chosen by the birds, being that one in which the color contrast was greatest; while in 4 the Melanoplus - straw and Xyphidium-straw combinations were about equally selected, the color contrast being very little different in either case. It is probable that the Melanoplus - grass combination would have been oftener selected, had the birds more frequently happened to alight on the side of the cage nearest to the grass.

Experiment 5.14 In this and the following experiment I employed backgrounds of mud and sand instead of grass and straw, placing at the outset of the experiment five Melanoplus on each background, those on the sand being (to my eye) the more conspicuous. In arranging these, I placed those on the mud background last, so as to attract, if possible, the birds' attention to these, rather than to those on the sand. A bird passed first to the sand background and took three insects. During the taking of these three the bird left the sand once and passed by the mud; and at another time it inspected the mud closely, but apparently without seeing the insects on it, as it did not take them at that time. Observation was then discontinued for a time and when renewed it was found that all of the remaining insects had been eaten.

Experiment 6. In this experiment five Xyphidium were placed on mud and five on sand. One bird flew to the mud past the sand, but without taking any insects from it. It then returned to the sand and ate all five placed on it. In this experiment the comparative resemblance and difference between the insects and their background was not as marked (to my eye) as in Experiment 5, but was still sufficient to influence decidedly the results.

Experiment \%. In this experiment five of each species of insects were placed on grass and five of each on straw. The birds passed the grass (one walking directly over it), and then flew up to their perch. Returning to the floor of the cage, they took two Melanoplus from the straw. Three of each species were now left on straw and five of each on grass. A bird came from the side of the cage nearest the grass and took three Melanoplus therefrom. In this latter case, as in Experiment 4 , the element of chance evidently decidedly influenced the results, the bird feeding from that background to which it first came. It is to be noted however that in this last case that species, Melanoplus, was taken which presented the greater contrast to the background (grass).

${ }^{14}$ In this experiment but one bird was employed, instead of two as heretofore. 


\section{Summary}

A summary of this series of experiments shows that of thirtyseven insects eaten in those experiments $(1,3,7$, and 4 , first part,) with four combinations of insects and backgrounds, nineteen or 51 per cent were taken from that background with which they made the greatest contrast, eighteen or 49 per cent from an intermediate background and none from that of least contrast. In those experiments in which there were but two combinations of insect and background (5, 6, and 4, last part) the prey was taken from the background of greater contrast in fourteen cases or 73 per cent and from the background of less contrast in five or 27 per cent. ${ }^{15}$ Considering the first choice of the birds rather than the total number of insects eaten, we find that in the four combination experiments, the combination of most contrast was chosen in nine out of thirteen cases or 69 per cent, an intermediate combination in four or 31 per cent and the combination of least contrast in none. In those experiments with but two combinations, we find the first choice of the birds to have been the combination of greater contrast in five cases and that of less contrast in none.

\section{SERIES IV}

In this series three young individuals of Krider's hawk (Buteo borealis krideri) and dead mice (Microtus drummondi and Mus musculus) and shrews (Sorex personatus haydeni and Blarina brevicauda) were used.

The hawks were taken from the nest just before learning to fly and kept in a cage $1.5 \times 3.9 \times 3.7 \mathrm{~m}$. in size. At one end of this cage backgrounds of different substances were prepared upon which the prey was placed. ${ }^{16}$ During the latter operation, the hawks were on a perch at the opposite end of the cage about one meter from the ground, care being taken not to attract

${ }^{15}$ See Experiment 5. The insects were taken from the mud (less contrast) background in this experiment only after at least three (possibly all five) had been eaten from the sand (greater contrast background).

${ }^{16}$ Dorsum uppermost except as otherwise noted. 
the notice of the birds more to one background than to another. While the prey in most cases contrasted much more strongly with one background than with the other, it was nevertheless distinct (to my eye) on both at the distance from which the hawks viewed it, the color contrast and resemblance not being very great in any case. In spite of this fact, in a large percentage of the experiments, the prey was taken from the background of greater contrast. In all except Experiments 16 and 17, the direction of the light was either directly or obliquely in the face of the birds. It is noteworthy that in these two experiments, the prey was taken from the background showing less, while in the others it was taken chiefly from the one showing greater contrast. Whether there was any relation between the direction of light and the results of the experiments, or whether the results in Experiments 16 and 17 were merely a coincidence, I cannot say.

Experiment.1. Figure 2. One Blarina was placed on earth and one on lime. One hawk left its perch and after flying about the cage two or three times dropped to the ground and espying the shrew on the lime, ran directly to it and stood watching it for several minutes, but did not seize it. It apparently did not see the other shrew. In this and the following experiments (up to No. 9 inclusive, and 14, 16, and 17) the greater contrast was presented by the prey on the lime background.

Experiment 2. Figure 2. Four alternating backgrounds, two each of lime and earth were prepared in this experiment, and one Microtus placed on each. Three hawks on perch. One immediately left the perch, flew to the ground and took one mouse from the lime.

Experiment 3. Figure 2. Two backgrounds, one of lime, and one of earth, were employed in this experiment, and one Microtus placed on each. Three hawks on perch. For about three-quarters of an hour the mice remained unnoticed by the hawks, although one of the latter flew across the cage once during this interval. I then drove a second hawk from the box, which flew across the cage, dropped to the ground and ran directly to the mice, but apparently did not see them. Then the first hawk flew to the mice and took one from the earth. ${ }^{17}$

${ }^{17}$ It is very possible that this mouse had been disturbed by the second hawk which was standing close to it when it was seized by the first, the attention of the latter being thereby attracted to it. I have often noticed that a hawk will be attracted to its prey, which it has previously apparently not seen, by another hawk seizing it. 
Experiment 4. Same as Fxperiment 3. The hawks remained on their perch for five minutes, taking no notice of the mice. I then drove one of the hawks from its perch. It flew across the cage and returned, dropping to the ground near the perch. It then immediately ran across the cage and took the mouse from the lime. After eating this, it took the mouse from the earth.

Experiment 5. Figures 1 and 3. One Mus on lime and one on earth over which were scattered a few scraps of leaves. $A$ hawk left its perch almost immediately after I left the cage and dropped to the ground below. A few seconds later it walked across the cage and took the mouse from the lime.

Experiment 6 . The same species of prey and the same backgrounds were employed in this experiment as in Experiment 5. Two hawks left the perch in succession and dropped to the ground, one of them within $0.6 \mathrm{~m}$. of the mice and somewhat nearer the mouse on the earth background. The latter hawk took the mouse from the lime.

Experiment \%. In this experiment the same species of mice and the same backgrounds were employed, but the backgrounds were reversed in position. Two hawks left the perch together and flew to the ground, one of them taking the mouse first from the earth background, and then from the lime.

Experiment 8 . The prey and the background arrangement were the same in this experiment as in Experiment 7. One hawk soon left the perch and flew to the ground near the backgrounds, but apparently did not see the mice as it retreated a short distance and remained for several seconds with its attention apparently fixed on something outside of the cage. Then it appeared suddenly to see the mouse on the lime and quickly seized it. The hawk was possibly 6 or $7 \mathrm{~cm}$. nearer the mouse on the lime than that on the earth when it espied the former.

Experiment 9. The same prey and the same backgrounds were employed in this experiment as in the preceding, except that the earth background was moved a few centimeters nearer the perch than the lime background. Three minutes after starting the experiment, a hawk left its perch and dropped to the ground about midway between the perch and the backgrounds. It remained there for a few seconds without apparently seeing the mice. Then it suddenly ran to the lime background from which it took a mouse.

Experiment 10. Figure 10. In this experiment the same prey was employed as in the last experiment, but the position of the mice was reversed, they being placed with the venter uppermost, one on a background of earth and the other on one of dry leaves of corn (Zea), the latter background replacing in position that of lime in the last experiment. In this experiment the contrast between the mice and earth was greater than that between the mice and the corn leaves. After four minutes, one hawk flew directly from the perch to the earth background and took the mouse from it.

Experiment 11. Figure 4. In this experiment the same prey was employed as in the last experiment. The prey was placed venter 
uppermost. Two backgrounds were employed, one of dry earth mixed with lime and dead leaves, the other of moist earth. The contrast between the mouse and the latter background was much stronger than that between the mouse and the former background. In ten minutes one hawk left its perch alighting near the mice but apparently not seeing them till after alighting. It alighted with its head turned away from the background of moist earth and facing the mixed background. After alighting it seized the mouse on the latter.

Experiment 12. Figures 1 and 14. The same prey and backgrounds were employed in this as in the last experiment, but the mouse on moist earth was placed venter uppermost, while that on mixed lime, leaves, and earth, was placed dorsum uppermost, the former presenting the more striking contrast. In six minutes a hawk left the perch and flying dircetly to the mice seized the one on the moist earth.

Experiment 13. The arrangement of backgrounds and prey employed in this experiment was precisely the same as in the last, except that the position of the backgrounds was reversed. For eighteen minutes the hawks remained on the perch, during which time one hawk looked down several times and appeared undecided whether to fly down or not. It finally flew directly to the backgrounds and took the mouse from the moist earth.

Experiment 14. Figures 1 and 8. In this experiment one background of lime and one of mixed lime, earth, and leaves was employed one Mus being placed on each. After about seventeen minutes, during which time the hawks remained on their perch, one of them circled over the mice and returning lit near the perch. It remained here for a few minutes with its back turned toward the mice, while a second hawk in about three minutes flew directly to the mouse on the lime, which it seized.

Experiment 15. Figures 2 and 13. One light colored Mus and one Blarina were placed on moist earth. After thirtecn minutes a hawk left the perch and flew to the ground near the prey, and then returned to the perch. Six minutes later a hawk flew to the background and lit with its side toward the shrew. After alighting (apparently not before) it saw the mouse, which it seized, and then took the shrew. In this experiment the greater contrast with the background was presented by the mouse.

Experiment 16. Figures 6 and 11. One background of lime and one of mixed earth, lime, and dry leaves were arranged in this experiment, and on each was placed a Microtus. Three minutes after the mice were placed a hawk left its perch and flew to a point between the backgrounds and close to each. It then retreated a few steps, returned and seized the mouse on the mixed background.

Experiment 17. Figures 1 and 8 . The same backgrounds were employed in this experiment as in the last, two Mus being used as prey. In three minutes a hawk left its perch and flying to the ground took the mouse from the mixed background. 


\section{Summary}

In eleven (Experiments 2, 4, 6, 8 to 10,12 to 15 ) of the above seventeen experiments or 65 per cent the combination showing greater contrast was chosen by the birds, and in five (Experiments $3,7,11,16$, and 17) or 29 per cent that of less contrast was selected, while in one (Experiment 1) although the prey was not seized by the hawk, the latter was evidently attracted by the combination of greater contrast. Experiments 3, 11, and 15 are doubtful for reasons already stated. ${ }^{18}$ Omitting these and Experiment 1, we have the following results:

Combination of greater contrast chosen in ten cases or 77 per cent, that of less contrast in three or 23 per cent.

\section{SERIES V}

In this series two ${ }^{19}$ young hawks (Buteo borealis krideri) and mice (Microtus drummondi, Peromyscus gambeli bairdi, Mus musculus) and rats (Epimys norvegicus) were used. The hawks were taken from the nest before learning to fly and confined in a cage $5.0 \times 2.4 \times 1.5 \mathrm{~m}$. in size, at one end of which were several perches placed from 0.3 to $1.0 \mathrm{~m}$. from the ground. At the opposite end of the cage backgrounds (described under the different experiments) were prepared, upon which was placed the prey. ${ }^{16}$ Care was taken while placing the latter to avoid attracting the attention of the hawks. This however was probably not a matter of great importance, as the latter seldom noticed the prey until several minutes after I had left the cage.

Experiment 1. Figure 9. Two backgrounds, one of moist earth, and one of ashes, were employed in this experiment, on each of which a Microtus was placed (venter uppermost). The mice were partly imbedded in each background so as to expose only the under surface, legs and tail. The white belly of the mouse on the earth presented a much stronger contrast with its background than that of the mouse on the ashes did with its background. Both hawks were on one of the perches at the opposite end of the cage and remained there for about a half hour evidently not seeing the mice. Then I disturbed

${ }^{18}$ See footnote ${ }^{17}$ and italicized lines in Experiments 11 and 15.

${ }^{19}$ In Experiments 15 to 19 three hawks were used. 
one of the two birds, which flew part way across the cage alighting a trifle nearer the earth than the ash background and remained there for another half hour. At the end of this time, one of the birds (which is uncertain, as I was not looking at the moment) took the mouse from the earth and almost immediately afterwards the mouse on the ash background was taken (probably by the same hawk).

Experiment 2. Figure 3. In this experiment two Mus were employed, one being placed on moist earth mixed with dead leaves and the other on ashes. Viewed from a point approximately one meter beyond the hawks' perch, the former mouse was invisible to me in the growing dusk, while the latter was plainly seen. In about two minutes, one hawk left its perch, flew directly to the ground about $0.3 \mathrm{~m}$. distant from the mice, paused for a second and then took the mouse from the ashes.

Experiment 3. This was a repetition of Experiment 2, except that the position of the backgrounds was reversed. In about ten minutes a hawk flew directly from its perch to the ash background and took the mouse from it.

Experiment 4. Figures 4 and 8. Two Mus were placed (venter uppermost), one on ashes and one on moist earth. In this experiment the greater contrast was presented by the latter combination, but the resemblance between the mouse and the ashes was not very close, as I observed it from the opposite end of the cage. Furthermore, in the dusk (6.12 p.m., Sept. 27) objects on ashes are much more conspicuous than those on earth. In one minute a hawk dropped to the ground near its perch, paused for a few moments, and then ran to seize the mouse on the ashes.

Experiment 5. Figures 3 and 15. One Mus was placed on light clay and one on dark earth covered with scattered bits of dead leaves. For thirty-eight minutes the mice were not disturbed. During this time one of the hawks three times left its perch, flew part way across the cage and returned to its perch, while the other one left its perch, flew over the backgrounds and returned. Then the latter left its perch a second time, dropped to the ground and ran almost directly to the clay background from which it took the mouse. The contrast in this experiment was greater botween the mouse and the clay than between the mouse and the earth.

Experiment 6. Figure 14. Two Mus were placed venter uppermost, one on light clay and one on dark earth. Both were partly embedded in the background so as to bring the ventral surface flush with it, thus eliminating shadow effects and the contrast between the darker sides of the mouse and the light clay. For one hour and twentytwo minutes the mice were apparently unnoticed by the birds, although during this time both birds left their perches and flew to the ground, and one of them flew over the backgrounds and alighted near them. At the end of this time the other flew over the mice and lit close to them, taking the mouse from the clay. In this experiment the mouse-earth was the combination showing greater contrast. 
Experimen \%. Figure 5. In this experiment two Mus were placed venter uppermost on dark earth and two on a mixture of dead leaves of the cottonwood tree (Populus) and the staminate branches and the styles of corn (Zea). As viewed from the opposite end of the cage, the resemblance between the mice and this latter background was close, while the mouse-earth combination presented a strong contrast. In six minutes a hawk flew direct to the backgrounds and picked a mouse from the earth.

Experiment 8. The arrangement of this experiment was the same as Experiment 7, except that only one mouse was placed on each background. In one minute a hawk dropped to the ground from its perch and ran to a point near the backgrounds, but did not feed. One minute later the other flew from its perch direct to the backgrounds and took the mouse on the earth.

Experiment 9. The arrangement here was the same as in Experiment 8 , except that the backgrounds were reversed in position, and the venter of the mouse on the earth was brought flush with the earth's surface. It was twilight when the experiment was started (5.54 p.m., September 28). In nine minutes a hawk flew from its perch directly over the mice but apparently did not notice them. In twenty-cne minutes the other flew direct to the backgrounds and took the mouse on the earth.

Experiment 10. Figure 3. Two Microtus were employed in this experiment, one being placed on ashes and one on a background of dark earth over which were scattered pieces of bark and dead leaves. The mouse on the latter background was plainly visible to my eye from the opposite end of the cage, but the contrast between the mouse and the ash background was much plainer. After looking at the mice for several seconds, a hawk flew direct to the backgrounds and took the mouse from the ashes.

Experiment 11. This experiment was the same as the last but the position of the backgrounds was reversed. In seven minutes a hawk after looking at the backgrounds flew to within several centimeters of them, paused a moment, and then took the mouse from the ashes.

Experiment 19. Figure 3. In this experiment two Peromyscus were placed venter uppermost one on ashes mixed with a little earth and one on earth. The venter of each mouse was brought flush with the surface of the background. As scen from the opposite end of the cage, the resemblance between the mouse and the ashes was so close as to render it invisible to my eye. In eight minutes a hawk flew to the ground at the middle of the cage, and walking slowly to the backgrounds took the mouse from the earth. Shortly afterward the other hawk passed very near the other mouse, but did not notice it. Five minutes later, however, the former hawk took it.

Experiment 13. Figure 16. A smaller Mus was placed on ashes and a larger one on earth mixed with a little ashes and partly covered with bits of bark, dead leaves and straw. The rescmblance here between the mouse and the lattor background was close. In twenty- 
one minutes a hawk flew to the ground at the middle of the cage and alighted facing the mice, but they were apparently not seen. Four minutes later it ran slowly to the mice and took one from the ashes.

Experiment 14. Figures 1 and 16. Two Mus were placed on ashes, and two on earth covered with dead leaves. The contrast between the mice and the former was greater than between them and the latter background, but the resemblance with the latter was not very striking. About fifteen minutes later one hawk flew to the ground within a short distance of the mice, but apparently did not see them. A few minutes later the other did the same, and fifteen minutes later flew over the mice alighting near them, but taking no notice of them. Then for twenty minutes the experiment was not observed. During this time both mice were taken from the ashes and neither from the leaves, although the latter were not over 22 or $23 \mathrm{~cm}$. from the former.

Experiment 15. Figures 13 and 16. Two Mus were placed on ashes and two on dead leaves. The former combination showed the greater contrast, but the resemblance between the mice and the leaves was only fair. In twenty-eight minutes a hawk ran across the cage to where the mice were, and returned without feeding, twice repeating this performance a few minutes later. About an hour after the experiment started another hawk took one mouse from the leaves. ${ }^{20}$ I failed to observe whether the hawk went directly to the mice or not.

Experiment 16. Figures 19 and 20. Two Epimys were placed venter uppermost, one on ashes and one on moist earth. Both were partly imbedded in the backgrounds, so as to expose only the ventral surface. As I viewed the backgrounds from the opposite end of the cage the former rat was clearly visible, but the latter was the more conspicuous. Seventy-two minutes after the experiment was started a hawk approached the backgrounds and stood inspecting the rats until another hawk ran from the opposite end of the cage and took the rat from the earth. It was growing dark at this time.

Experiment 17. Figures 22 and 23. Two Epimys were placed on powdered gypsum and two on dead leaves, sticks and straws mixed with a little clay. The resemblance between the rats and the latter background was not very close, as viewed from the opposite end of the cage, but was much closer than that of the rats to the gypsum. For several hours (exact time not recorded) the rats were not taken by the hawks, although the latter frequently looked toward them and one once or twice alighted within about $3 \mathrm{~m}$. of them. I then tied a string to one of the rats and jerked it repeatedly, causing the hawks to look toward the rats, but without any move to take them. I then removed a rat from each background, leaving one on each, and ceased observing the experiment for twenty-five minutes. Returning at the end of this time, I found one of the hawks eating the rat on the gypsum. The hawks were undoubtedly hungry in this experiment as they had had only one rat between them during the two preceding days, and why

${ }^{20}$ That one of the two was taken which resembled its background less closely. 
they were so slow to feed is a mystery. It cannot be explained as due to unfamiliarity with the rats as food, for they were accustomed to feed upon them. I shall refer to this question later (p. 493).

Experiment 18. This was a repetition of the preceding experiment. For an hour and a half the birds were not observed. At the end of this time I returned to the cage and found a hawk eating the rat on the gypsum.

Experiment 19. Figures 19 and 21. Two Epimys were placed, venter uppermost, one on ashes mixed with gypsum, earth and clay, and one on moist earth. Both were partly imbedded in the backgrounds so as to bring their bellies flush with the surface of the latter. The rat-earth combination showed the greater contrast of the two. After an hour and twenty minutes returning to the cage I found two hawks fighting over the rat on the earth.

\section{Summary}

In this series of nineteen experiments, the combination of greater contrast was chosen in sixteen or 84 per cent of the cases and that of less contrast in three or 16 per cent: In one of the latter (Experiment 4) the light was such at the time of experiment that objects on a light surface (ashes) were in general much more visible than those on a dark surface (moist earth). In another of these (Experiment 6) it is probable that the hawk did not see the mice until it alighted close to them, at which distance the resemblance between the mouse and the clay could not have had much effect. I shall consider this point further in my discussion of results. In Experiments 1, 2, 3, and 14, also, the weak light enhanced the effect of the white background. If these six experiments $(1,2,3,4,6$, and 14), regarding which some uncertainty was introduced by the conditions just mentioned, be removed from the count, the results stand: Combination showing greater contrast chosen in twelve out of thirteen experiments (92 per cent), that of less contrast in one (8 per cent).

\section{SERIES VI}

In this series a long-eared owl (Asio wilsonianus) and house mice (Mus musculus) were employed. The former was taken from the nest in June just before learning to fly and kept in a small cage until October, when the experiments were performed. 
For a few days it was fed by hand, but it soon learned to feed itself. The experiments were conducted in the same cage in which Series V was conducted. The backgrounds were arranged at one end of the cage and the prey placed on them while the owl was perched at the opposite end, care being taken, as in the other experiments, to conceal the mice from the view of the owl while they were being placed on the backgrounds. In all of the experiments to be recorded the contrast between the mice and the white background (snow or powdered gypsum) was much greater than between the mice and the other background. ${ }^{21}$ Being performed at dark or later, the effect of the former background in rendering objects placed upon it conspicuous in comparison with those on the other backgrounds was much enhanced. The resemblance between the mice and the latter backgrounds may have been greater to my eye than to that of the owl, since its eyes were adapted to night vision. When the owl was transferred from the small to the large cage and mice first placed on the backgrounds, it left them untouched for about three hours, at the end of which time, observation was suspended. It soon learned however to feed from the backgrounds and did so much more readily than the hawks in Series IV and $V$.

Experiment 1. Figures 7 and 11. Four mice were placed on snow and four on dead leaves mixed with earth and clay. Fifteen minutes later three mice had been taken from the snow.

Experiment 2. The arrangement of prey and backgrounds was the same in this experiment as in the preceding, except that only two mice were placed on each background. In less than an hour ${ }^{22}$ one mouse was taken from the snow.

Experiment 3. Figure 14. In this experiment three mice were placed venter uppermost on partly moist clay and three in a similar position on moist earth. The clay and earth backgroundsoccupied the same relative position as the snow and leaves in the preceding experiment. At the time of this experiment, the latter combination, as seen from the opposite end of the cage, presented a much greater contrast than the former. Within about five minutes the mouse nearest the clay background was taken from the earth.

Experiment 4. The same as Experiment 3, except that the clay had become more moistened by the underlying damp earth, and the

21 Experiments 3 to 5, 9, 10 excepted.

22 Exact time not noted. 
resemblance between it and the bellies of the mice was correspondingly lessened. Within ten minutes one mouse was taken from the clay. The mouse taken in this experiment was nearer the baseboard of the cage than the other two on the clay. On this baseboard the owl frequently alighted after flying across the cage from its perch.

Experiment 5. Same as Experiment 4, except that only one mouse was placed on the earth. Within thirteen minutes it was taken from the latter.

Experiment 6 . Figures 8 and 13. Six mice were placed on gypsum and six on moist clay mingled with leaves, straw, etc. ${ }^{23}$ Almost immediately the owl flew directly to the gypsum and took a mouse therefrom.

Experiment 7. Same as Experiment 6, with same result.

Experiment 8. Same as Experiment 6, except that only four mice were placed on each background. In six minutes, the owl flew directly to the gypsum and took a mouse from it.

Experiment 9. Figure 14. Four mice were placed venter uppermost on moist earth, and four on clay, the backgrounds being sufficiently excavated to bring the bellies of the mice flush with their surfaces. The relative positions of the backgrounds in this experiment was again reversed to the original position. Within twenty-four minutes one mouse was taken from the earth.

Experiment 10. The same as 9, but position of backgrounds reversed. The following morning I found four mice removed from the earth and one from the clay.

Experiment 11 . Figures 8 and 11 . One mouse was placed on gypsum and one on leaves mixed with moist earth and clay. Within five minutes, the mouse was taken from the former background.

Experiment 12. Same as Experiment 11, except that the backgrounds were reversed in position. The owl flew back and forth across the cage several times, twice alighting on baseboard of cage nearest the background of earth and leaves. In about ten minutes it alighted on the baseboard a third time, remaining there for ten or twelve minutes more. Soon after (exact time not recorded) the mouse was taken from the gypsum. Sometime during the night the mouse was taken from the leaves.

\section{Summary}

In eleven out of twelve experiments or 92 per cent the combination of greater contrast was chosen, and in the other experiment (4) the resemblance between the mouse chosen and its background was not great, and the owl probably alighted nearer to it than the other background before feeding.

\footnotetext{
${ }^{23}$ In this and the two succeeding experiments, the position of the light and dark backgrounds was the reverse of that in the preceding experiments.
} 
Series VII and VIII were conducted simultaneously and the birds (kingbird-Tyrannus tyrannus and grackle-Quiscalus quiscula anaeus) confined in the same cage. ${ }^{24}$ The kingbird was taken from the nest before learning to fly while the grackle was an adult which flew into a building and was caught there. In Series VII the latter bird was employed as the preyer, and in Series VIII the former. In each series several different species of insects (as recorded for the individual experiments) were used as prey. Different backgrounds (the character of which and the relative contrasts between them and the insects placed thereon being noted in each experiment) were prepared at one end of the cage, while the birds were perched at the opposite end, care being taken in each case to avoid attracting the attention of the birds more to one background than to the other while the prey was being placed upon them. The insects in each case were killed before being placed in position.

Experiment 1. Figures 33 and 37. Five Melanoplus ${ }^{7}$ were placed on hay and five on sand. In fifteen minutes the grackle dropped to the ground and walked to the hay from which four grasshoppers were taken followed by four from the sand. The contrast between the grasshoppers and the sand was greater than that between them and the hay, but their resemblance to the latter background was not very great. The bird seemed afraid of those on the sand, drawing back in apparent alarm after seizing one.

Experiment 2. Figures 25 and 44. One Gryllus pennsylvanicus was placed on sand and one on moist earth. The former combination presented the greater contrast, but a little sand accidentally mixed with the earth reduced the resemblance between the cricket and the latter background. After three minutes the grackle flew over the backgrounds twice, apparently taking no notice of either cricket. Five minutes later it alighted nearer the earth background, from which it took the cricket.

Experiment 3. Same as Experiment 2. In one minute the grackle flew to the ground alighting nearer the cricket on the earth, which was taken one minute later.

Experiment 4. Figures 37 and 50. One Melanoplus was placed on grass and one on sand. The contrast here was greater in the latter than in the former combination. The grackle immediately dropped

${ }^{24} 3.6 \times 1.8 \times 1.6 \mathrm{~m}$. in size. 
to the ground and then walked to the backgrounds, somewhat nearer the grass, but took the insect from the sand.

Experiment 5. Figures 25 and 58 . One Oecanthus quadripunctatus was placed on grass and one on moist earth. The grackle at once dropped to the ground, approached the grass first and took the insect therefrom. The contrast here was greater in the insect-earth than in the insect-grass combination.

Experiment 6. Same as Experiment 4. In one minute the grackle flew across the cage to a point nearer the grass than the sand, but walked past the former to take the insect from the latter background, although it was smaller than that on the former.

Experiment 7. Figures 35 and 58 . One Oecanthus was placed on grass and one on sand, the latter combination presenting the greater contrast. The grackle flew at once to a point nearer the grass background from which the prey was taken.

Experiment 8. Same as Experiment 4 . The grackle at once dropped to the ground and in two minutes passed the grass to take the insect on the sand background.

Experiment 9. Same as Experiment 7. The contrast here was only slightly greater between the insect and the sand than between the former and the grass. The grackle almost immediately dropped to the ground, passed the grass and then turned back and took the inseet from it. It then picked some crumbs from the sand. Evidently the insects were not seen by the bird before it reached the backgrounds.

Experiment 10. Same as Experiment 5. After twenty minutes the grackle approached the grass from which it took the insect, then taking that on the earth.

Experiment 11. Figures 25 and 37. Three Melanoplus were placed on hay mixed with moist earth, and three on sand. The latter combination showed the greater contrast. The grackle passed first to the hay from which it took the insects and then to the sand from which they were next taken.

Experiment 12. Figures 25 and 58. Four Oecanthus were placed on moist earth and four on grass, the arrangement being as shown in the accompanying diagram (fig. B). The grackle's line of approach and the order of seizure of the insects are also shown in the diagram. The grackle approached the backgrounds and began feeding in one minute after the start of the experiment. The contrast in this experiment was greater between the insects and the earth than between the former and the grass.

Experiment 13. Figures 40 and 55. One Gryllus was placed on a mixture of burnt paper and moist earth and one on ashes. For some time (time not noted) the grackle remained on its perch. It then How to the ground and began picking up various small scraps of food, finally approaching the backgrounds, but stopping to peck at something when but a few centimeters distant. It then took the cricket from the earth and next that from the ashes. The contrast between 
the cricket and the grayish-white ashes was greater than that between the former and the dark background. The accompanying sketch (fig. C) shows the arrangement of the backgrounds and the line of the birds' approach (xy) and the point $(\mathrm{x})$ where it stopped to pick up a particle of food.

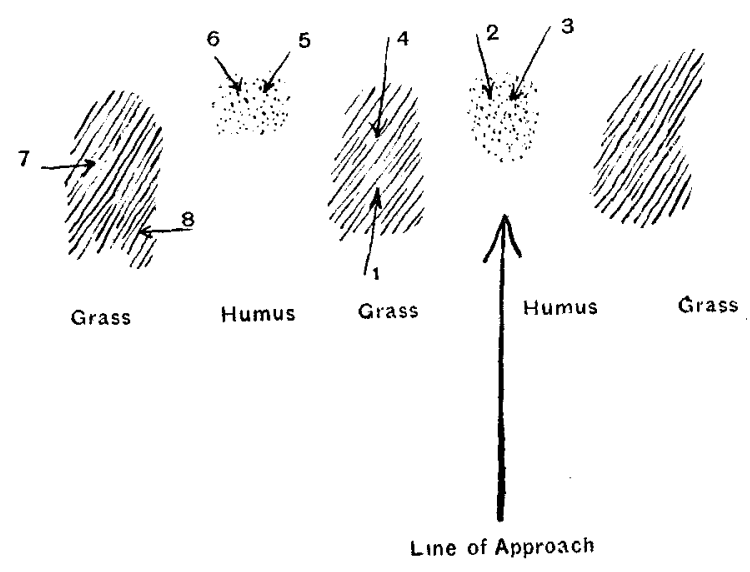

Fig. B The figures indicate the positions of the insects on the backgrounds, and the order of their seizure.

Experiment 14. Figures 40 and 43 . One Gryllus was placed on scraps of burnt paper and one on ashes. The resemblance between the cricket and the paper was close and the contrast between the former

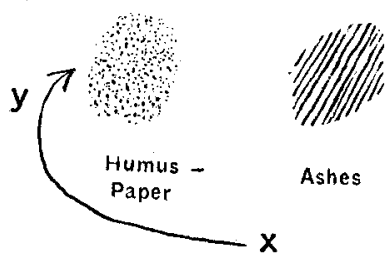

Fig. C

and the ashes was strong. After five minutes the grackle flew to the ground close to the latter background, from which it took the cricket. It then took that on the paper. Although the bird flew directly to the backgrounds in this experiment it apparently did not see the insects until after alighting, for it turned from its first position in order to seize its prey.

Experiment 15. Figures 24 and 30. Two Melanoplus were placed on ashes and two on a mixture of dead leaves, straw, and earth, the 
former combination presenting the greater contrast. The grackle at first flew to a perch about $2 \mathrm{~m}$. from the backgrounds, from which, three minutes after the start of the experiment it flew to the ground near the latter background, but passed it by and attempted to scizo an insect on the former when I interrupted it.

Experiment 16. Same as Experiment 15. In about seven minutes, the grackle flew over the backgrounds alighting nearer the ashos, but seizing an insect from the leaves and straw.

Experiment 1\%. Figures 30 and 46 . Two Silpha surinamensis were placed on burnt hay and two on ashes. In twenty minutes the gracklo, flew to the ground at the middle of the cage and began foeding. It soon approached the backgrounds on the side of the burnt hay background, from which it took a beetle. The contrast herc was greater between the beetles and the ashes, but the resemblance between the hay and the beetles was not very close as the latter were a glossy black and the hay dull black.

Experiment 18. Figures 27 and 30. Two Silpha were placed on light ashes and two on charred wood, the former combination presenting much the greater contrast. In one minute the grackle dropped to the ground and began fecding. In two minutes it passed the beetles on the black background and took both from the white, taking no apparent notice of the former.

Experiment 19. Same as Experiment 18, except that only onc beetle was placed on each background. In one minute the grackle flew to the ground beside the white ashes from which it took the beetle. It then passed the black background once or twice taking no apparent notice of the insect upon it. After fourteen minutes the latter was taken, but I am uncertain whether by the kingbird or the grackle.

Experiment 20. Same as Experiment 19. The grackle immediately flew to the ground and approaching the white background first took the insect from it. It then took the insect from the black background.

Experiment 21 . Figures $2^{n}$ and 45. One Silpha on charred wood and one on flour, the latter combination presenting the greater contrast. The grackle at once approached the backgrounds in a fairly direct line, passing nearer the wood, but taking the bectle from the flour. It then took the beetle from the wood.

Experiment 2Q. Figures 36 and 60. One moth (Noctuid sp.) was placed on a piece of bark which was partly covered with damp ashes producing a background closely resembling the moth, and one on a strip of very light colored wood. ${ }^{25}$ The body of the insect was inserted in a crack in the bark so as to bring its partly expanded wings close to the surface of the latter, but not in anyway concealing it. The grackle flew from one perch to another and then returned. It then flew to the ground and fed for a few minutes. In ten minutes it approached the backgrounds, passed close to the moth on the bark, and took that from the wood. It was seemingly a little suspicious of the

${ }^{25}$ A piece of an ordinary berry box was used. 
latter, as it dropped it once before eating it. It then turned back and took the moth from the bark.

Experiment 23. Figures 40 and 42. One Gryllus was placed on ashes and one on a mixed background of charred and uncharred wood, the latter combination presenting a close resemblance, and the former a good contrast. The grackle immediately dropped to the ground and began feeding. It soon went to the backgrounds, passing nearer the charred wood, but taking the cricket on the ashes. It then turned and walked over the charred wood, passing directly over the cricket upon it, but apparently not seeing it.

Experiment 24. Same as Experiment 23, except that in the former both crickets were probably in shadow, ${ }^{26}$ while in this experiment they were in the sun. The grackle immediately dropped from its perch to the ground and approached the backgrounds about midway between them, paused a moment and seized the cricket on the ashes, after which it turned and took that on the wood background. The prompt approach of the grackle to the backgrounds in this experiment apparently indicates that it realized that food had been prepared for it there. Its attention however was not I believe attracted to one background more than to the other in the preparation of the experiment. Its pause for a moment after reaching the backgrounds, and the prompt seizure of both insects suggests that both were seen as it approached, and that it was a matter of chance, or possibly of some individual preference on the part of the bird as to which was taken.

Experiment 25. Figures 51 and 53. One green Melanoplus was placed on grass and one on charred wood. For three-quarters of an hour the insects were untouched, although the grackle several times went to within a short distance of the backgrounds. For seven minutes the observations were discontinued. Soon after resuming them, the grackle once again approached to within about $3 \mathrm{~cm}$. of the backgrounds but did not feed. Then it again approached, coming nearer the charred wood, from which it seized the insect, and then immediately took one from the grass. The charred wood combination presented the greater contrast. That the insects were left untouched for so long a time in this experiment, because of the bird not being hungry, is improbable, as it was pecking at objects on the bottom of the cage during this time, and when one insect was finally taken the other was immediately taken also. Further, in the following experiment (26), the grackle took the insects very soon after the experiment was started and within about ten minutes of the last feeding (in Experiment 25).

Experiment 26. Same as Experiment 25. The grackle immediately dropped to the ground and approached the backgrounds. It turned back for a moment and then re-approaching between the two backgrounds, took the insect on the charred wood and immediately after, that on the grass.

Experiment 27. Figures 49 and 51. One green Melanoplus was placed on a mixture of grass and straw (lengthwise on a straw so as

${ }^{26}$ On this point my notes are uncertain. 
to more closely resemble its surroundings), and one on charred wood, the latter combination showing the greater contrast. Before I had left the cage after placing the insects, the grackle crossed from the opposite end of the cage to the backgrounds and took the insect from the charred wood, leaving that on the grass and straw untouched. This was left in position and a few minutes later it too was taken. Comparing Experiment 25 above with Experiment 27, one is impressed with the influence which the attention of the bird exercised on the rapidity with which the results were obtained. In the former experiment, the insects were apparently unseen for over fifty minutes, although during this time the bird several times came near them; while in the latter they were taken immediately, due in all probability, to the fact that the bird realized that food was being prepared for it on the backgrounds. Why its attention was attracted more readily in one experiment than in another is uncertain. I shall refer to this question later (p. 493).

Experiment 28. Figures 27 and 61. One moth (Noctuid sp.) was placed on brown leaves and bits of bark and one on charred wood within about $7 \mathrm{~cm}$. of each other. The former moth closely resembled its background, while the latter combination presented a good contrast. In three minutes the grackle dropped from its perch to the ground and walked directly to the backgrounds, passing by the moth on the leaves. It then paused for a few seconds to inspect the moths, before seizing that on the charred wood, immediately followed by that on the leaves.

Experiment 29. Figures 26 and 27 . Same as Experiment 28, except that a background of straw was substituted for the leaves and bark, the moth-wood combination presenting the greater contrast. The grackle immediately dropped to the ground and walked directly towards the backgrounds, but its attention being apparently diverted by some object outside of the cage, it ran past, returning on the side of the straw, from.which it seized the moth, and then that on the wood.

Experiment 30. Figures 27 and 59. One moth (Noctuid sp.) was placed on charred wood and one in an angle of a dead leaf so that the wings overlay it, with the head and thorax projecting over the ground, thereby reducing the relief and enhancing the resemblance of the insect to its background The insects were placed 6 or $7 \mathrm{~cm}$. apart. In ten minutes the grackle dropped to the ground and approached the backgrounds on the side of the latter moth, but passed it by and seized the former, then turning, it apparently was about to seize the latter when I interfered.

Experiment 31. Figures 27 and 40. One Gryllus was placed on charred wood mixed with a little earth, and one on ashes. The former combination presented to my eye a close resemblance. The grackle was about $1.6 \mathrm{~m}$. distant during the arrangement of the experiment. As I was leaving the cage it went directly to the backgrounds and approaching the charred wood first, seized the insect upon it, immediately followed by that on the ashes. 
Experiment 32. Same as Experiment 31, except that the grackle was further distant from the backgrounds at the beginning of the experiment. The result was the same as in Experiment 31.

Experiment 33. Figures 27 and 60. One moth (Noctuid sp.) was placed on gray bark and one on charred wood, the former presenting, to my eye, a fairly close resemblance to its background, and the latter a good contrast. After flying across the cage a few times the grackle dropped to the ground and a minute later went directly to the backgrounds, passing the charred wood and taking the insect from the bark, followed by that on the charred wood.

\section{Summary}

In 15 out of 33 experiments, or 45 per cent, the combination of less contrast was chosen and in 18 out of 33 , or 55 per cent, that of greater contrast. In 15 , or 45 per cent, the prey was taken from that background nearest which the bird happened to alight. A further analysis of these apparently inconclusive results will be reserved for later discussion.

\section{SERIES VIII}

Experiment 1. Figures 25 and 37. Five Melanoplus were placed on sand and five on a mixed background of hay and earth, the former combination presenting the greatest contrast. Almost immediately the kingbird flew direct to the sand from which it took one insect.

Experiment 2. Same as Experiment 1. In three minutes the same result was obtained.

Experiment 3. Same as Experiment 1. In one minute the kingbird flew over the sand alighting on a box about $2.5 \mathrm{~cm}$. from the backgrounds. Here it remained a few moments when the same result was obtained.

Experiment 4. Same as Experiment 1. The kingbird immediately flew to the sand from which it took one insect, and then alit at a point nearer the hay than the sand. It quickly returned and first seized one insect on the hay and then the remaining four on the sand, leaving four on the hay.

The results in the three preceding experiments may have been modified by the memory of the bird's experience in Experiment 1, in which it found insects on the sand. In Experiment 4 however even after it fed from the hay, it left four insects on the latter and took four from the sand, tending to show that this was not the case.

Experiment 5. Figures 35 and 58. One Ceresa bubalus was placed on grass and one on sand, the latter combination showing the greater contrast. Before I had time to leave the cage the kingbird flew to the sand, from which it took the insect. 
Experiment 6 . Same as Experiment 5. In twelve minutes the kingbird flew direct to the sand from which it took the insect. It then looked closely at the insect on the grass for a few seconds and then took it also.

Experiment \%. Figures 25 and 30 . Three Melanoplus were placed on backgrounds of hay mingled with earth and three on ashes, as shown in the accompanying diagram (fig. D). The latter combination showed the greater contrast. The kingbird flew to the backgrounds, while I was standing nearby, going first to 5 , but not feeding. It then took the insect from 1 .

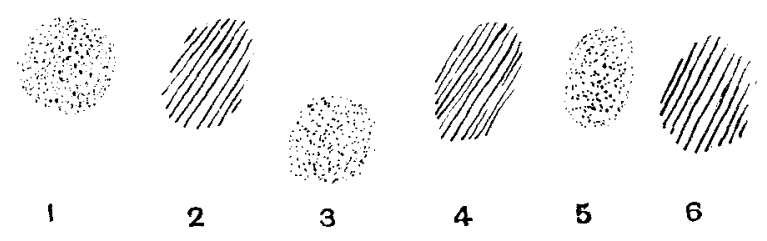

Fig. D 1,3, and 5 -ashes; 2,4 , and 6 -hay-earth.
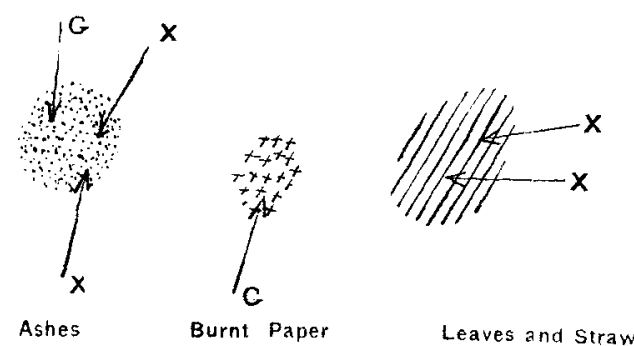

Fig. E $g$-Gryllus, $x$-Melanoplus.

Experiment 8. Same as Experiment 7. The kingbird flew direct to 5 , which it took followed by 1 . The result in Experiment 8 may have been modified by that in Fxperiment 7 , as both were alike.

Experiment 9. Figures 24, 30, 40 and 43. In this experiment three backgrounds were prepared, the arrangement of which, with the insects placed on each is shown in the accompanying sketch (fig. E). The leaf and straw background was in weak sunlight, while the ashes were in sharlow. The insects on the ashes presented the greatest contrast to their background in this experiment. Within two minutes, and while I was still standing near the backgrounds, the kingbird flew direct to the ashes from which it took both Melanoplus.

Experiment 10. Same as Experiment 9, except that all the backgrounds were in shadow at the time of experiment. At the commencement of this experiment the kingbird was perched on the side of 
the cage. ${ }^{27}$ In thirty seconds it flew direct to the ashes from which it took one Melanoplus, returning to its usual perch. A few seconds later it left its perch and circled over the backgrounds, returning to the perch and then it again flew direct to the ash background, from which it took the other Melanoplus. For five minutes it flew back and forth from point to point in the cage, at one time alighting near the backgrounds but not feeding. The observations were then discontinued.

Experiment 11. Figures 25 and 34. Two Oecanthus were placed on dark earth and two on a background of mingled sand and ashes over which were distributed grass stems and awns closely resembling in color the insect's wings, the former combination presenting the greater contrast. In five minutes the kingbird flew from the perch to a point on the walls of the cage nearly over the backgrounds which it closely inspected. It then flew across the cage and returned to this point from which one minute later it dropped to the backgrounds and a moment later took one insect from the earth. Two minutes later it again flew to the backgrounds ${ }^{28}$ and took the other insect from the earth. The two insects were left on the grass and sand background and in about ten minutes the kingbird alit near them twice but took no apparent notice of them. The observations were ended after about thirty-five minutes up to which time they had not been taken.

\section{Summary}

In this series of eleven experiments the combination showing the greater contrast was chosen eleven times. This is the only series in which protective coloration was efficient in 100 per cent of the trials.

\section{SERIES IX}

In this series the domestic chicken (Gallus domesticus) and various species of insects, as recorded in the individual experiments, were employed.

The experiments while few in number cover a series of years (1910, '11, and '12) and were conducted in different cages, the size of which I believe to be immaterial, as the chickens always walked up to the backgrounds, giving them abundant opportunity to see their prey at close quarters. I have therefore not recorded the size of cage in the various experiments. One bird was used in Experiments 1 to 7, another in 8 to 11, and a third

${ }^{27}$ Distance from backgrounds not noted.

${ }^{28}$ The point from which it flew was not noted. 
in Experiment 12. Care was taken in arranging the experiments to avoid drawing the attention of the chicken more to one background than to another.

Experiment 1. Figures 27 and 48 . One Platynus placidus was placed on charred wood and one on ashes, the latter forming the combination of greater contrast. The chicken was about $2.5 \mathrm{~m}$. distant from the backgrounds, from where it walked toward them, stopping for a few moments when a few centimeters distant from them. It then took the insect from the charred wood.

Experiment 2. Figures $2^{7}$ and 54. One Oecanthus quadripunctatus was placed on charred wood and one on flowers of the golden rod (Aster). The light green of the insect's body and the straw color of its wings presented a close resemblance to the latter background, while the contrast of the former combination was good. The chicken slowly approached the backgrounds from a point about $3 \mathrm{~m}$. distant. Approaching from the side of the golden rod background, it passed this and took the insect from the charred wood. Then immediately turning back it took the insect from the former background.

Experiment 3. Same as Experiment 2 and precisely the same results in all details.

Experiment 4. Same as Expcriment 2 and same result except that the chicken in passing the golden rod background stepped on it and upset the insect, which it apparently did not see as it did not take it, but moved away after eating that on the charred wood.

Experiment 5. Same as Experiment 2 except position of backgrounds reversed and a larger head of golden rod employed. The chicken approached the charred wood background from a point about $2.5 \mathrm{~m}$. distant. It apparently first saw the insect on the charred wood when but a few centimeters away, for from that point it ran to the wood and took the insect from it. It then paused a moment and turned away, but returned to take the insect from the golden rod.

Experiment 6. Figures 27 and 40 . One Gryllus pennsylvanicus on ashes and one on charred wood, the former combination showing the greater contrast. The chicken approached the ash background from a point $3.5 \mathrm{~m}$. distant, which it passed to take the cricket on the charred wood. It then moved around the backgrounds, but did not touch the insect on the ashes. After some three minutes I transferred the insect from the ashes to the charred wood and a few minutes later the chicken took it. Here apparently the chicken had some antipathy to the ash background. But note the result in Experiment 7 .

Experiment $\%$. Figures 54 and $5 \%$. One Oecanthus was placed on ashes and one on flowers of the golden rod (Aster), the former combination presenting the greater contrast. The chicken was about $3.5 \mathrm{~m}$. distant. It approached the backgrounds gradually on the side of the golden rod background but took the insect from the ash first and immediately after that from the golden rod. 
Experiment 8. Figures 40 and 41 . One Gryllus was placed on coa dust mixed with small pieces of anthracite coal, the latter shining like the insect's head and thorax, and one on ashes, the latter combination showing much the greater contrast. The chicken was about $1.5-2 \mathrm{~m}$. distant. It approached slowly on the side of the coal background from which it first took the insect and immediately after that on the ashes.

Experiment 9. Same as Experiment 8. The chicken wandered around for about three minutes and then approached the background on the side of the coal, but took the cricket from the ashes, followed immediately by that on the coal.

In both Experiments 8 and 9 the chicken several times passed near the backgrounds (within a half meter) without apparently seeing the insects before it finally took them.

Experiment 10. Figures 30 and 38. One Melanoplus was placed on earth over which were scattered bits of dry leaves and one on ashes,

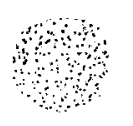

A

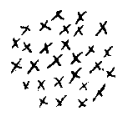

B

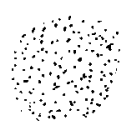

c

$x$

Fig. F

the latter combination showing the greater contrast. The chicken was about $1.5 \mathrm{~m}$. distant. Almost immediately it approached the backgrounds but passed them and then turning back took the insect from the ashes and a few seconds later took that on the earth background. During this interval the insect on the latter was apparently unnoticed by the chicken.

Experiment 11. Figures 25 and 40. Three Gryllus were placed on each of two backgrounds of moist earth, $A$ and $C$, and three on ashes, $B$, arranged as shown in the accompanying sketch (fig. F). The latter combination showed greater contrast. The chicken was about $2 \mathrm{~m}$. distant at the beginning of the experiment. After a minute or two it approached the backgrounds to $X$, within about $0.5 \mathrm{~m}$. of them, without apparently seeing the insects. From here it went to $C$ and took three, and then two from $B$ and one from $A$.

Experiment 12. Figures 31 and $4 \%$. In this experiment several backgrounds, some composed of sifted lime and some of a mixture of earth and straw, were arranged alternately at one end of the cage. Six Melanoplus were placed on the lime backgrounds and six on the earth and straw, the former combination forming a strong contrast; the latter a close resemblance. A hen was then turned loose in the cage. She soon approached the backgrounds, taking four insects from the strawearth backgrounds and then four from the lime. 


\section{Summary}

In this series the combination showing the greater contrast was chosen in seven out of twelve cases or 58 per cent and the one showing the less contrast in four or 42 per cent. It is noteworthy that in this series, as well as in series II and III, the birds usually approached their prey slowly, giving them opportunity to carefully inspect the backgrounds at close range before making their choice.

Two experiments were also performed with the prairie chicken (Tympanuchus americanus) and the grasshopper (Melanoplus), one background of lime and one of earth and straw being employed (figs. 31 and 47). Results similar to those of the last series were obtained, the bird in each case walking to the backgrounds and taking the insects from that one which it first approached, in one case the lime, in the other the earth-straw background.

All of the experiments recorded above are open to the objection that they were performed with caged birds (most of them young individuals) which as a result of confinement may not have acquired the normal keenness of vision. So far as I am aware, most of the experiments on protective coloration (including mimicry, warning coloration, etc.) which have been recorded thus far have been performed with caged animals, but it is quite possible that confinement does in many instances render less acute an animal's senses. While none of the birds experimented with became very tame, ${ }^{29}$ some of them, notably the hawks, Buteo borealis krideri, behaved very differently from wild birds. One of these, when removed from the cage, instead of flying off, remained on the ground as long as observed, and when I approached attempted to defend itself by fight, rather than flight. While this condition militates against the value of my experiments, I believe it is far offset in the other direction

${ }^{29} \mathrm{~A}$ short time after removal from the nest the martins (Progne subis) became so tame that they would climb up my leg in order to obtain food, while the young kingbirds occasionally fed from forceps held in my hand. As the birds grew older they soon lost this tameness however, and would not permit me to approach them elosely when possible to avoid it. 
by the smallness of the cages in which the birds were confined. Thus instead of being obliged to seek their prey from a considerable distance as is the case with many wild birds, notably hawks, it was brought close to the caged birds, thereby reducing very materially the protective coloration effect.

I have made several attempts to perform similar experiments with wild birds, but in most instances without success. Wild birds ordinarily have an abundance of food available, so that they will pay no attention to food prepared for them, especially if the food be dead, while their natural food is alive. It is highly probable moreover that movement of their prey plays a large rôle in enabling raptorial and insectivorous birds to secure it. To this latter point I shall refer later.

In a few cases, however, I secured results which will be recorded in the following experiments.

\section{SERIES $\mathrm{X}$}

Experiment 1. Figures 29 and 50. In this experiment three backgrounds were arranged as shown in the accompanying diagram (fig. G), 1 and 3 being composed of blades of grass and $\mathscr{Z}$ of flour. Five Melanoplus were placed on 1 and $B$ and ten on 2 . The latter combination presented the greater contrast. About $45 \mathrm{~cm}$. from 1 and 8 to 10 . $\mathrm{cm}$. above the level of the backgrounds was a perch, $A$. Two minutes after arranging the backgrounds two English sparrows (Passer domesticus) lit near them and fed from each leaving three insects on 1 , seven on 2 and one on 3 . Seven minutes later a kingbird (Tyrannus tyrannus) lit on the perch and then flew over 1 to 2 where it took one insect. It then took three from 1 and two more from 2 . When viewed from the perch then at a distance of $46 \mathrm{~cm}$. the color of the insects was protective, but at closer range this effect was lost.

Experiment 2. Figures 29 and 32. In this experiment two backgrounds were arranged in the same position as in Experiment 1, 1 being composed of a mixture of straw and dry ditch grass (Ruppia maritima) and 2 of sifted flour, on each of which were placed seven Melanoplus. The latter combination presented the greater contrast. A grackle (Quisealus quiscula anaeus) soon fed from cach background feeding from that one (2) which it first approached, from which it took one, and then two from one of the others. A kingbird then flew over both backgrounds and lit on the perch. It then flew over 1 and took an insect from 2 .

Experiment 3. The same as Experiment 2 except that five insects were placed on each of the two backgrounds. After a sparrow had alighted and fed on 2 , a kingbird flew over both backgrounds to alight 
on the perch, shortly after returning to 2 and feeding while on the wing. When I examined the backgrounds all had been taken from 2 and none from 1 .

Experiment 4. The same as preceding except that nine insects were placed on each background. A sparrow, after alighting on the perch, flew over 1 and fed from 2 .

Experiment 5. Figures 28 and 50. The backgrounds and a perch were arranged as shown in the accompanying sketch (fig. $\mathrm{H}$ ), the perch being about $60 \mathrm{~cm}$. away from the backgrounds, and ten Xyphidium fasciatum were placed on each background, the insect-flour combination showing the greater contrast. A sparrow lit on the perch and then flew to 1 from which it fed.

Experiment 6. Same as Experiment 5. A sparrow alighted on the perch and then flew to 2 but did not feed, passing instead to 1 from which it took one insect.

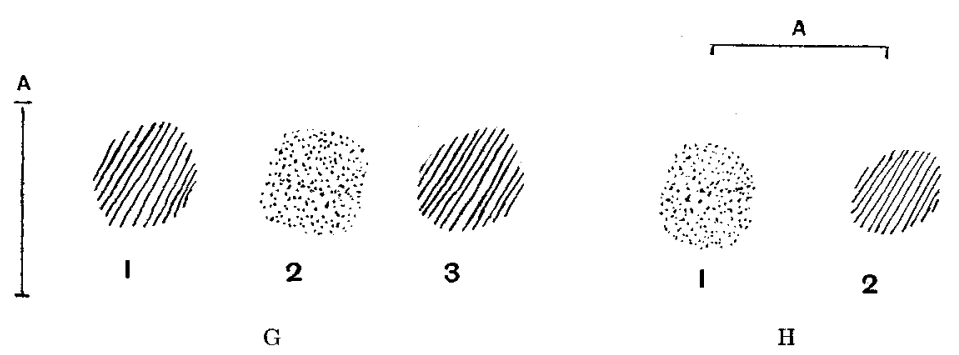

Figs. G and $\mathrm{H} \quad A$-perch, 1-flour, 2-grass.

Fourteen other similar experiments were performed but in these cases the birds with one exception hopped up to the backgrounds and fed from the one which they first approached, the exception being that of a kingbird which, flying close to the ground, and approaching the background presenting the less contrast first, fed from it on the wing.

\section{Summary}

The results of this series agree closely with the experiments in the preceding series; in those cases in which the birds approached the backgrounds slowly on foot, the similarity in color between the prey and the backgrounds, had less apparent protective value $3^{30}$ while in those cases on the contrary in which the birds approached the backgrounds on the wing, even from a short distance, the resemblance between the prey and the backgrounds showed an evident protective effect.

${ }^{30}$ See pp. 496-7. 
In regard to my experiments with the martin and kingbird (Series III and VIII) the further objection may be made that I obliged birds, which normally feed on flying insects, to feed on insects placed on the ground. I can only say in answer to such an objection that I have observed both of these birds feed on the ground, and I have also seen the kingbird and other swallows (Chelidon and Tachicineta) feeding from the surface of a lake.

In the course of these experiments I have found considerable evidence to show that stillness is of more importance than color in determining the immunity of animals to attack by birds. I have frequently found the prey which I had placed on the backgrounds unnoticed by the birds for several minutes, or even in some instances hours, although the latter were unquestionably hungry, and in many cases were running about the cage, pecking at various objects on its floor. Especially was this delay noticeable in series IV and V with the hawks (Buteo borealis krideri).

The failure of hungry birds in many instances to notice the food prepared for them on the backgrounds, ${ }^{31}$ may be attributed to the dulling of their senses by captivity, in the case of those birds which were taken from the nest and reared in captivity. This will hardly, however, explain such failure, in the case of the grackle (Quiscalus), which was taken when adult and had been a captive for only a few weeks previous to the experiments. It was kept, moreover, during this time in a large cage,,$^{32}$ freely accessible to light and air and was oftener hungry than the reverse.

If, however, the prey was thrown into the cage so as to attract the notice of the birds it was usually pounced upon immediately. In Series X I saw the kingbird (Tyrannus tyrannus) pass the backgrounds three times in one experiment without feeding, although it was feeding on nearby objects (undoubtedly living insects). In Series I, Experiment 2 a crow dropped a frog

${ }^{31}$ See for example Experiment 3, Scries IV, Experiment 17, Series V, and Experiment 25, Series VII.

$323.6 \times 1.8 \times 1.6 \mathrm{~m}$. 
which it had seized in order to pursue another frog which moved nearby; and in Series III, Experiment 1 a martin passed dead insects several times without noticing them, but seized a live specimen which I had left in the cage by mistake. In many other instances also, notably in Series VII, Experiments 9, 14, 23, etc., and Series IX, Experiments 8 and 9, the bird passed close to one or other of the backgrounds without apparently seeing the prey upon it.

In order to definitely test this point in the case of the hawks, (Buteo borealis krideri) I performed the following experiments:

\section{SERIES XI}

Experiment 1. A dead mouse (Mus musculus) placed at one end of the hawk's cage, while the bird was at the opposite end $4.5 \mathrm{~m}$. distant, was not noticed by the bird for scveral ininutes, until the latter was driven across the cage to where the mouse lay, when it was taken. A cage containing a living mouse, actively moving about, was now introduced into the hawk's eage, and no sooner was the mouse liberated from its cage than it was seized by the hawk.

Experiment 2. A dead rat (Epimys norvegicus) placed on the ground at one end of the cage with the hawk at the opposite end was seized in two minutes. A live rat released in the cage ran toward the hawk and when about one half the distance across the cage it was seized by the latter.

Experiment 3. Two mice (Mus musculus) were placed at one end of the cage with the hawk at the opposite end. One of these was dead and the other alive, attached to a small wire by one leg. After seven minutes the hawk seized the live mouse.

Experiment 4. Same as Experiment 3, with same result in five minutes.

\section{Discussion}

Birds are frequently given credit for an extremely acute vision and to this faculty is ascribed, by the opponents of the protective coloration theory, their power to discern their prey at long distances regardless of whether the latter is or is not protectively colored.

Thus Entz (1906, p. 136) says:

- . wo aber ist je eine Beobachtung darüber angestellt worden, ob sich die Schutzfarbe den Tieren des Waldes und der Luft gegenüber wirklich als solche bewährt oder ob etwa Vögel mit schärferen Sinnen 
die Raupe und den Schmetterling ebenso sicher erkennen wie der Adler aus gewaltiger Höhe den Hasen oder das Murmeltier auf gleichfarbigem Boden?

This assumption however lacks supporting evidence, and the experiments here cited tend to disprove it. True it is that raptorial birds frequently sail at great heights, but how many instances are on record of their swooping down from these heights to seize their prey? Furthermore anyone who has observed a hawk hovering in the air evidently in pursuit of prey, will realize that it is in all probability the movement of the latter which enables the hawk to follow and finally to seize it. This conclusion is supported by my own observations and experiments just cited.

I have observed numerous cases of ducks flying within gunshot of a hunter lying or sitting motionless upon the ground, without any blind to screen him from their sight. No sooner does the hunter rise to shoot however or the ducks come near enough to see him than they immediately swerve from their course and either turn back, or more often make a wide detour to avoid the threatened danger; proving that it is not fearlessness that brings them into danger, but inability to see a man close to the ground in a motionless posture, or at least to distinguish him from his surroundings.

In this connection the occasional records of birds seizing wooden decoys are of interest. Lawrence ('66, p. 279) says of the duck hawk (Falco anatum) "I have a fine specimen which was killed at Rockaway in the act of carrying off one of our wooden snipe decoys, which it had seized." ${ }_{33}$

Dr. Frank M. Chapman writes me that his "friend Dr. L. C. Sanford says he has seen a great horned owl attempt to seize a decoy," while Cleaves ('14) cites a case of the osprey (Pandion haliaetus carolinensis) seizing a wooden fish decoy.

I have heard indirectly of other instances so that the occurrence can not be very unusual.

${ }^{33}$ This record was kindly given me by Mr. Chas. W. Richmond of the U. S. National Museum. 
Now if birds have such keen sight as is frequently attributed to them, keen enough to discern protectively colored animals on their backgrounds, it seems unlikely that they should be unable to distinguish a man in crouching posture until within gunshot of him, or to distinguish between real and decoy birds.

In the case of insectivorous birds those which swoop down upon their prey from a distance, like the Tyrannidae, the Hirudinidae, etc., prey almost exclusively on moving insects, in which case color (apart from mimicry and warning color) can obviously have little or no protective value; while others, like the Icteridae, Sturnellidae, etc., approach their prey so closely before seizing it, that even if it were motionless, it would need to bear an exceedingly close resemblance to its background in order to escape their scrutiny.

Many of the experiments described in this paper, especially those of Series I, II, VII, and IX, are inconclusive for various reasons, some of which have been already stated in connection with the individual experiments. The chief reason however is, as already stated by me in a preliminary communication before the American Society of Zoologists (Young, '15), that in many of the experiments the approach of the birds to the backgrounds was deliberate and gave them ample time to inspect the latter carefully before the prey was seized. In this connection, see Experiments 6, Series V, 28, VII, 1, IX, etc. Under these circumstances it is probable that in many experiments chance determined the bird's choice, that combination being chosen, which was nearest to the point of the bird's approach. In this connection an analysis of the results of Series I, III, VII, and IX is of interest. My notes unfortunately do not indicate in every case the point of the bird's approach. The number of experiments in which this is indicated however is sufficient to enable a fairly definite conclusion to be drawn from them. of the forty-eight experiments, the combination presenting the greater contrast was chosen in twenty-six instances, and the one showing less contrast in twenty-two. The former may be called positive and the latter negative experiments. In the 
former the bird approached from the side of the chosen combination (showing greater contrast) in four cases (15 per cent), from the opposite side in eighteen cases (69 per cent), and took a middle course in four cases (15 per cent). ${ }^{34}$ In the negative experiments on the other hand, the approach was from the same side in 15 cases (68 per cent), from the opposite side in 5 cases (23 per cent), while a middle course was taken in 2 cases $(9$ per cent), which is nearly an exact reversal of the former proportions. This comparison shows perhaps even more clearly than do the results of the more definite series (III, VI, VIII, and X) the protective effect of color in the animals used in these experiments; for it shows that in spite of a deliberate approach of the birds to the backgrounds, it was possible to so far deceive them that in eighteen out of forty-eight cases they passed by the inconspicuous combination. On the other hand, in only five cases out of the forty-eight, did a bird pass over a conspicuous combination in favor of an inconspicuous one..$^{35}$ Further in Series III, the martins usually approached the backgrounds on foot, rather than on the wing, giving them also time to inspect the backgrounds more or less closely before feeding. Yet in spite of that fact, the results of this series show clearly the protective value of resemblance to the background in the case of motionless insects.

It is further to be borne in mind that the resemblance between the prey and the background in these experiments, was in many cases not very striking. Had animals with more striking resemblance to their surroundings been available for experiment, I am confident that even in experiments with crows, grackles, chickens, and birds of similar feeding habits still more marked results would have been obtained.

There is another factor also which possibly modified the results in a few cases. Namely, choice of the bird for one background over another, regardless of the relative contrasts presented by the combination of background and prey. This factor, I be-

${ }^{34}$ Percentages given to nearest unit only.

${ }^{35}$ In this connection, see Experiments 3 and 5 , Series I, 3, II, 4, 6, 8, 15, 18, $21,22,23,28$, and $30, \mathrm{VII}$, and $2,3,4,7$, and 9 , IX. 
lieve played a relatively small part in determining the results. That it may have been of some importance however is indicated in Experiment 6, Series IX.

It may be argued from these results that, since the birds find their prey chiefly through the movement of the latter, it is of no consequence in the struggle for existence whether or not an animal resembles its surroundings, proyided only that it remains quiet or hidden when exposed to attack. Unfortunately we have as yet no means of knowing the precise rôle which movement plays in animal fatalities. It is obvious even without experimental proof that a moving animal is more liable to attack than a quiet one, but as to what extent moving animals are killed by their enemies we have no definite data. Granting however which is probably true, that moving animals are more frequently killed than motionless ones; it is possible that protective resemblance would have sufficient selective value to become permanent. This of course leads up to the great question as to the efficiency of selection in fixing minor variations upon a race of organisms; a question with which the present paper has nothing to do, the purpose of the experiments being, not to determine this latter point, but rather to ascertain whether or not protective resemblance in the case of motionless animals is really an efficient means of protection to them.

This latter question has I believe been answered in the affirmative by these experiments. I have endeavored in them to put to an experimental test a hitherto practically untested hypothesis. They suggest further lines of desirable observation and experiment as follows:

1. Will close protective resemblances, such as those shown for example by many of the underwing moths, deceive animals of deliberate approach, such as crows, grackles, etc.?

2. Is protective resemblance efficient in the case of moving animals?

3 . Is the sight of wild birds as keen as is frequently assumed?

4. Is protective resemblance as efficient with wild as with captive animals? 
Many other lines of experiment in the great field of animal color will suggest themselves to every naturalist, but the ones just specified are those which suggest themselves as a logical sequence to those herein described.

\section{SUMMARY}

1. Protective resemblance is effective in protecting motionless animals from attacks by caged birds.

2. Stillness is probably a more important factor than color in protecting animals from their foes.

In concluding this paper, it is my pleasure to thank the United States Biological Survey through Mr. Vernon Bailey, and the United States National Museum, through Mr. Richard Rathbun, for the loan of material; and Messrs. Alf. Eastgate, Clark Kelly and Robt. Gray, of Devils Lake, North Dakota, for various courtesies, in connection with my work. 


\section{LITERATURE CITED}

Beddard, Frank E. 1892 Animal coloration. London and New York.

Cleaves, Howard H. 1914 Hunting with the lens. Nat. Geog. Mag., vol. 26, pp. 1-35.

Entz, G. 1906 Die Farben der Tiere und die Mimikry. Math. Nat. Ber. Ungarn, Bd. 24, pp: 71-201.

FrnN, FRANK 1898 Contributions to the theory of warning colors and mimicry. Jour. Asiatic Soc. Bengal, vol. 66, pp. 613-668 (and preceding papers on this subject in the same journal)..$^{36}$

Judd, Sru. D. 1899 The efficiency of some protective adaptations in securing insects from birds. Am. Nat., vol. 33, pp. 461-485.

LAwrence, G. N. 1866 Catalogue of birds observed on New York and Long Islands, and the adjacent parts of New Jersey. Ann. Lyceum of Nat. Hist. of New York, vol. 8, p. 279. (Not seen by me).

Poulton, E. B. 1890 The colours of animals. Appleton and Co., New York.

Prichett, Annie H. 1903 Some experiments in feeding lizards with protectively colored insects. Biol. Bull., vol. 5, pp. 271-287.

REIGHARD, J. 1909 An experimental field study of warning coloration in coral reef fishes. Carn. Inst. Wash. Publ. No. 103, pp. 257-325.

Werner, Franz 1907 Das Ende der Mimikry-hypothese. Biol. Centrbl., Bd. 27, pp. 174-185.

Young, R. T. 1915 Some experiments in protective coloration (Prelim.) Science, N. S., vol. 41, p. 475.

\footnotetext{
${ }^{36}$ Not seen by me.
} 
PLATES 


\section{PLATE 1}

\section{EXPJANATION OF FIGURES}

1 1, Mus on earth, leaves and lime; 2, Microtus and Blarina on moist earth; 3, Mus and Microtus on dry earth, leaves, and twigs.

2 1, Microtus and Blarina on moist earth; 2 , the same on lime.

31 , Microtus and Mus on ashes; 2 , the same on moist earth, leaves, bark, etc. Peromyscus placed venter uppermost, 1 , on ashes, 2 , on moist earth.

41 , Mus on dry earth mixed with lime and leaves; 2 , Mus on moist earth. Both placed venter uppermost.

51 , Mus on earth;, Mus on leaves of cotton wood (Populus) and styles and staminate flowers of corn (Zea). Placed venter uppermost.

6 1, Microtus on earth mixed with leaves, etc; 2, Microtus on lime.

7 1, Mus on earth, leaves, and lime; 2, Mus on snow.

8 1, Mus on ashes, venter uppermost; 2, Mus on lime; 3, Mus on gypsum.

9 1, Microtus on moist earth; 2, Microtus on ashes. Both placed venter uppermost.

101 , Mus on earth; 2 , Mus on leaves of corn (Zea). Both placed venter uppermost.

11 1, Microtus on mixed earth, lime, and leaves; 2, Mus on mixed clay, leaves and earth.

121 , Rana cantabrigensis on sand; 2 , the same on earth.

131 , Mus on moist earth; 2 , Mus on dead leaves; 3 , Mus on wet clay, leaves and straw.

141 , Mus on moist earth; 8 , Mus on clay. Both placed venter uppermost.

15 1, Mus on clay; 2, Mus on dry earth with scattered bits of leaves and twigs.

161 , Mus and Microtus on ashes; 2 , the same on moist earth, leaves, bark, etc.

17 1, Rana pipiens on sand; 2 , Rana pipiens on grass.

18 Rana pipiens on moist earth.

19 Epimys on moist earth, venter uppermost.

20 Epimys on ashes, venter uppermost.

21 Epimys on mixed ashes, gypsum, earth and clay. Venter uppermost.

22 Epimys on gypsum.

23 Epimys on leaves, sticks, and straws mixed with clay.

\section{ABBREVIATIONS}

$b$, Blarina brevicauda

$m i$, Microtus drummondi

$m$, Mus musculus

$p$, Peromyscus bairdi

Except as otherwise noted, the animals are in every case placed dorsum uppermost.

For an explanation of the methods employed in photography, see pp. 458-9 in the text.

Figs. $1,3,4$, and $9-1: 9 ; 2-1: 10 ; 5,14,15$, and $17-1: 8.5 ; 6-1: 9.5 ; 8-1: 7.5$; $7,11,13,16$, and $18-1: 8 ; 10-1: 6.5 ; 12-1: 7.5 ; 19$ to $23-1: 20 ; 28,29,31,32,55$, $57-8: 7 ; 48-6: 7 ; 49,51,53-4.3 ;$ all others $1: 1.5$. 


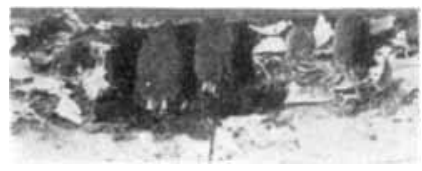

$$
m_{1} m_{1} m_{3} m_{1}
$$

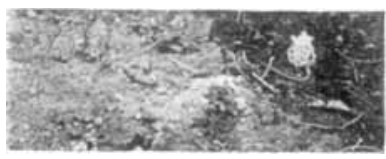

2

4
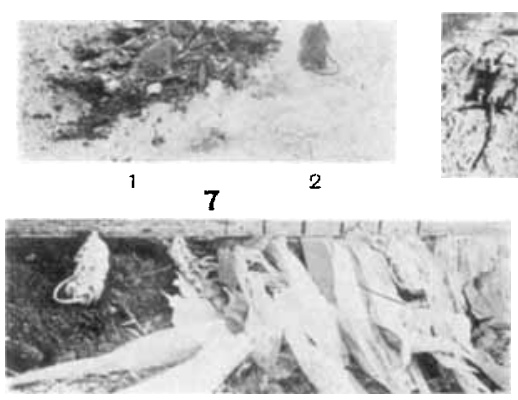

10

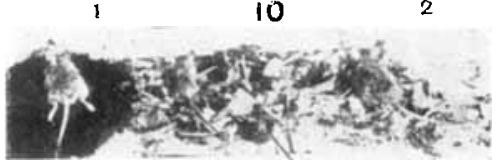

2

13

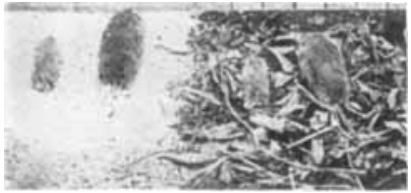

$m_{1} m_{1} \quad 16^{m_{2} m_{1}}$

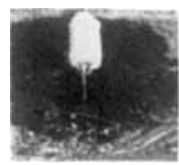

19

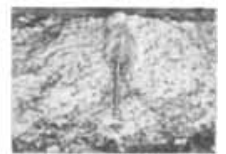

20

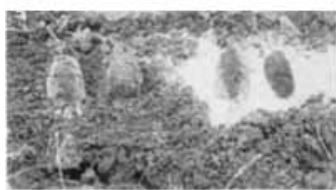

$\mathrm{mib}_{1} 2 \quad \mathrm{ml}_{2} \mathrm{~b}$
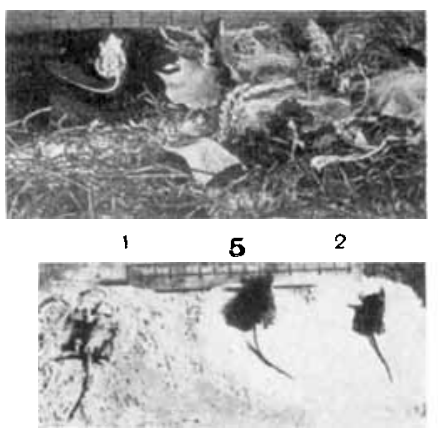

$1 \quad 8 \quad 2$
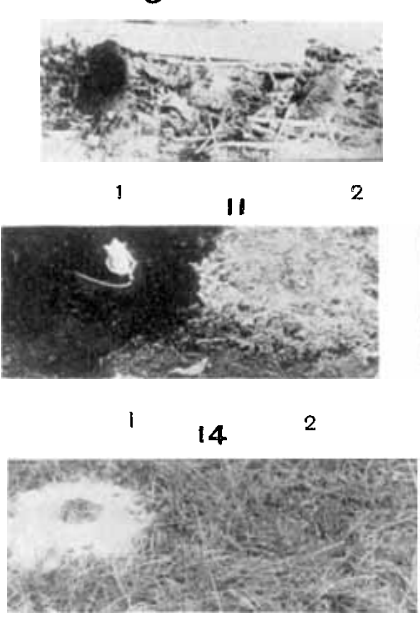

17

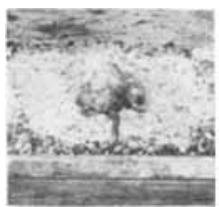

21

503

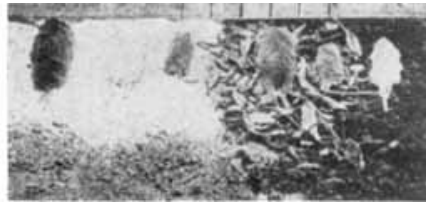

$m_{1} p_{3} m_{2} p$
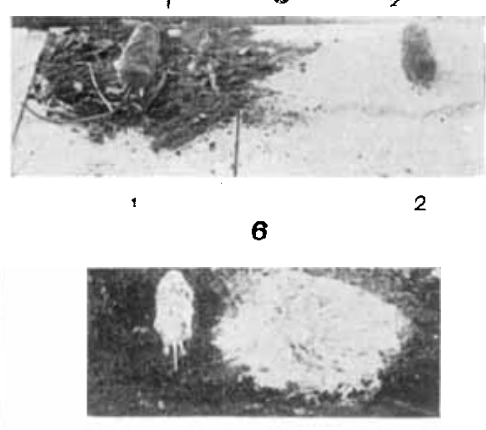

92

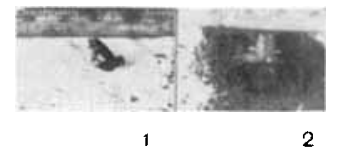

12
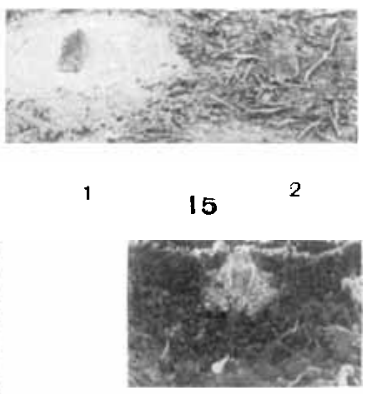

18

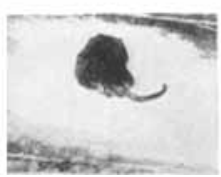

22

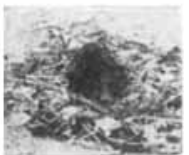

23 


\section{PLATE 2}

\section{EXPLANATION OF FIGURES}

24 Dissosteira on leaves; Melanoplus on leaves, straw, and earth.

25 Melanoplus on hay scattered over moist earth; Gryllus and Oecanthus on moist earth.

26 Noctuid sp. on straw.

27 Noctuid sp., Oecanthus, Gryllus, Platynus, and Silpha on charred wood.

28 Xyphidium on flour.

29 Melanoplus on flour.

30 Dissosteira, Melanoplus, and Silpha on ashes.

31 Melanoplus on lime.

32 Melanoplus on dry Ruppia and straw.

33 Melanoplus on hay.

34 Oecanthus on pale grass stems.

35 Oecanthus and Ceresa on sand.

36 Noctuid sp. on wood.

37 Xyphidium and Melanoplus on sand.

38 Melanoplus on earth and dry leaves.

39 Gryllus on flour.

40 Gryllus on ashes.

41 Gryllus on coal.

42 Gryllus on charred and uncharred wood.

43 Gryllus on burned paper.

ABBREVIATIONS

$c$, Ceresa bubalus

$d$, Dissosteira carolina

$g$, Gryllus pennsylvanicus

me, Melanoplus spp.

$n$, Noctuid moth sp. $o$, Oecanthus quadripunctatus

$p$, Peromyscus bairdi

$s$, Silpha surinamensis

$x$, Xiphydium fasciatum 
R. T. YOUNG
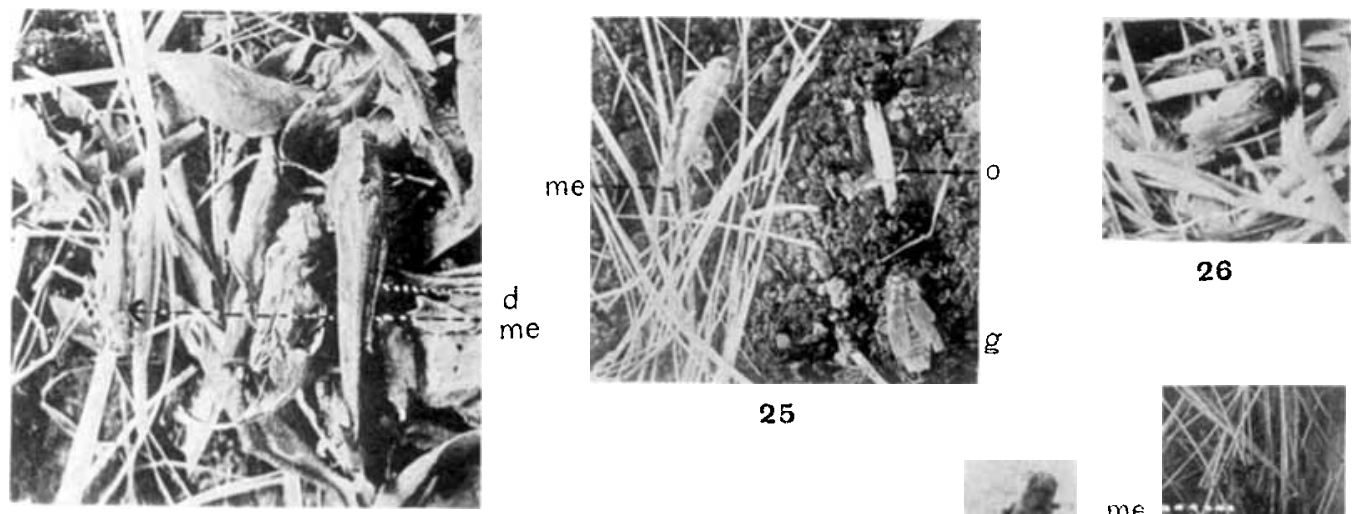

26
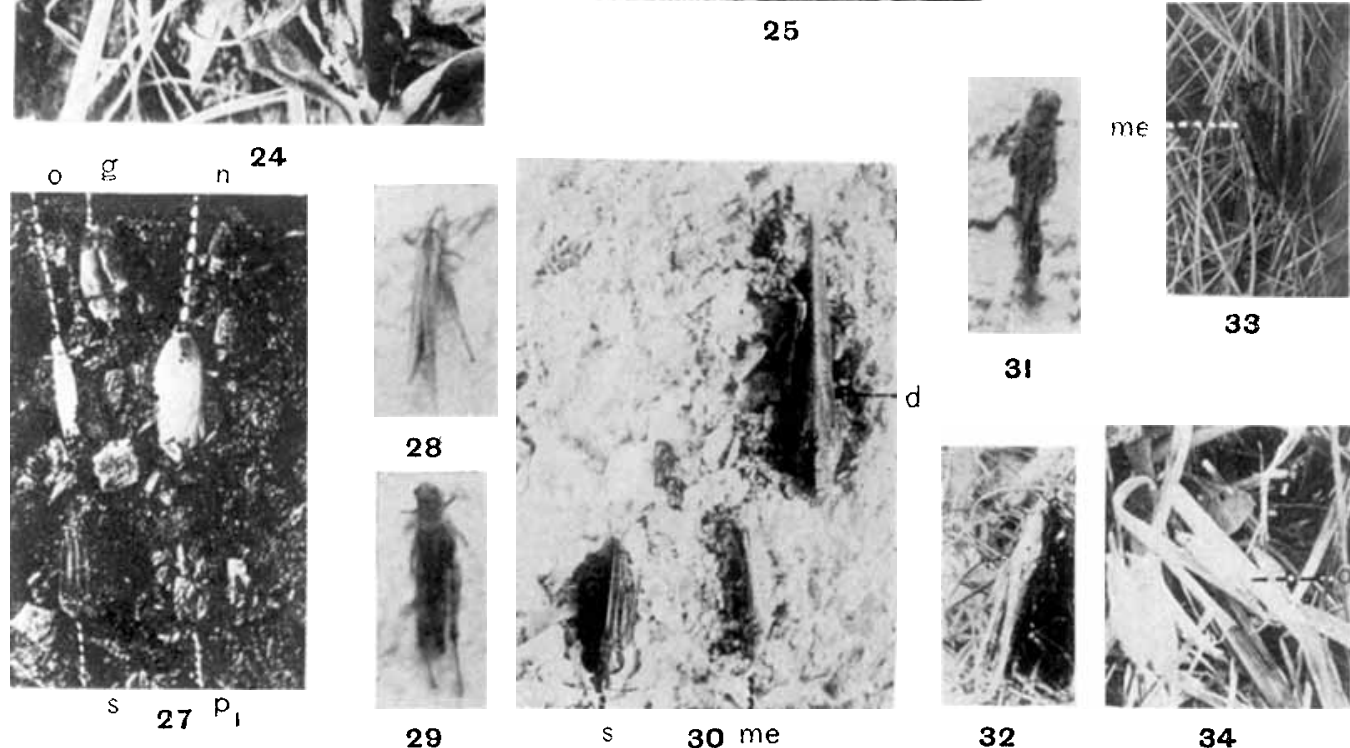

31
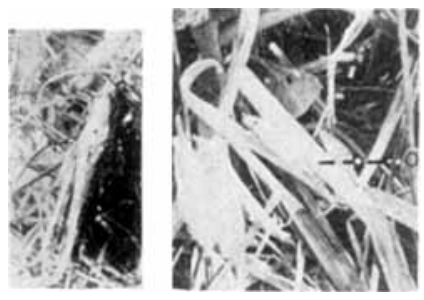

34

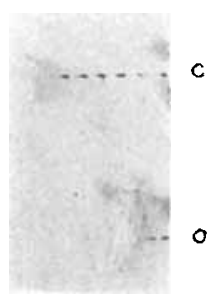

35

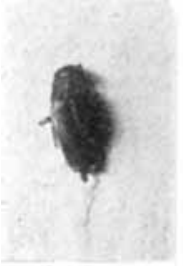

39

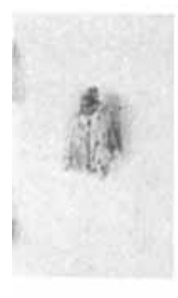

36

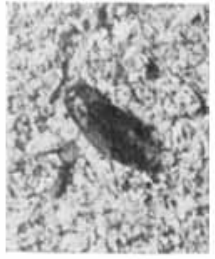

40

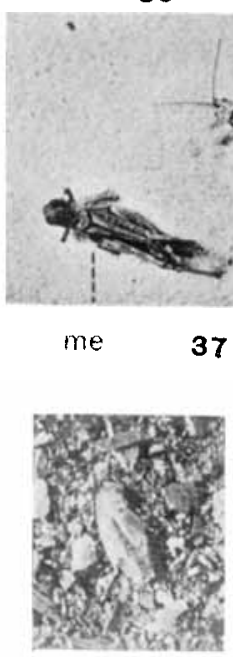

41

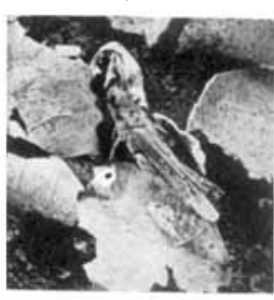

38

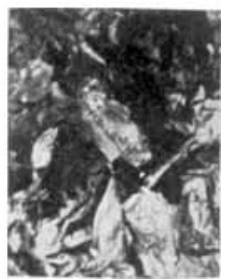

43

505 
PLATE 3

\section{EXPLANATION OF FIGURES}

44 Gryllus on sand.

45 Silpha on flour.

46 Silpha on burned hay.

47 Melanoplus on straw and earth.

48 Platynus on ashes.

49 Melanoplus on grass and straw.

50 Xyphidium and Melanoplus on grass.

51 Melanoplus on charred wood.

52 Xyphidium and Melanoplus on straw.

53 Melanoplus on grass.

54 Oecanthus on flowers of Aster.

55 Gryllus on moist earth and burned paper.

56 Xyphidium and Melanoplus on moist earth.

57 Oecanthus on ashes.

58 Oecanthus and Ceresa on grass.

59 Noctuid sp. on dry leaf.

60 Noctuid sp. on bark.

61 Noctuid sp. on earth and dry leaves.

\section{ABBREVIATIONS}

c, Ceresa bubalus me, Melanoplus spp. $n$, Noctuid moth sp. $o$, Oecanthus quadripunctatus $x$, Xiphydium fasciatum 

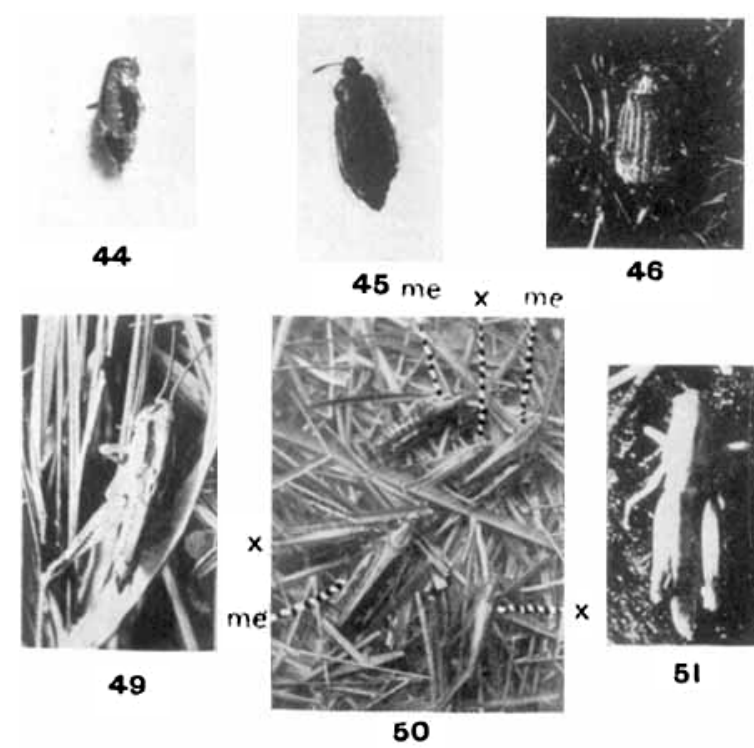
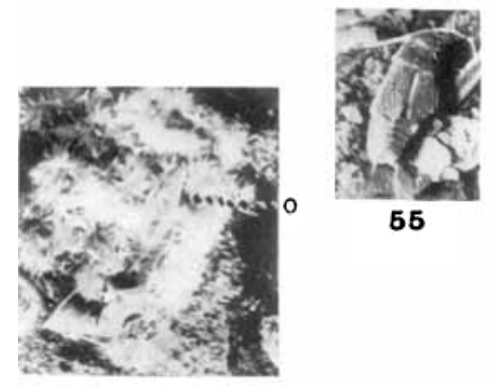

54

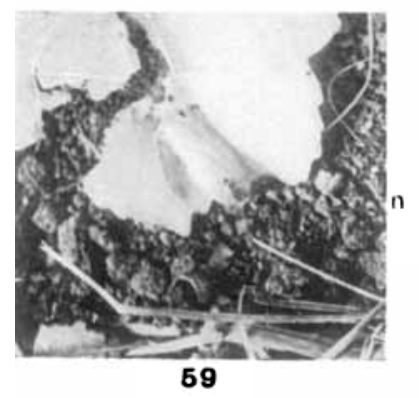

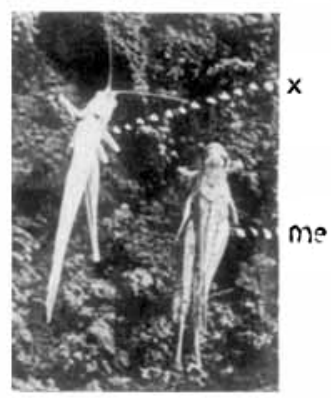

56

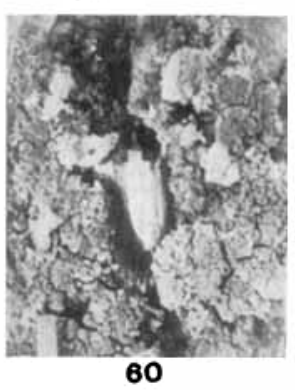

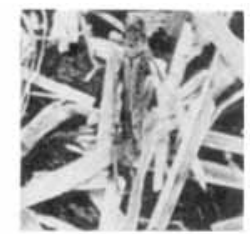

47
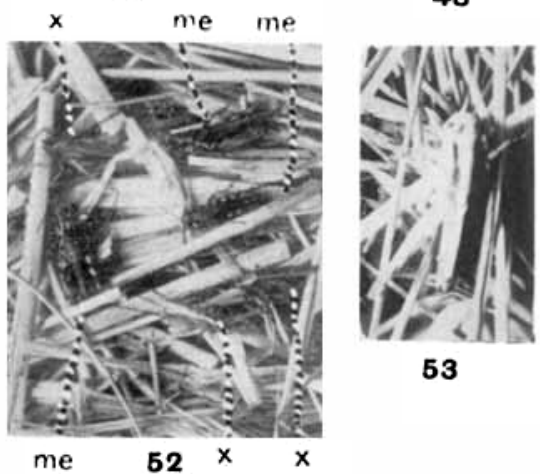

53

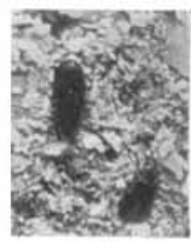

48 $\mathbf{5 1}$

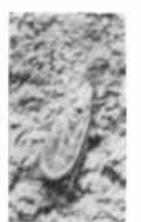

$\mathbf{5 7}$
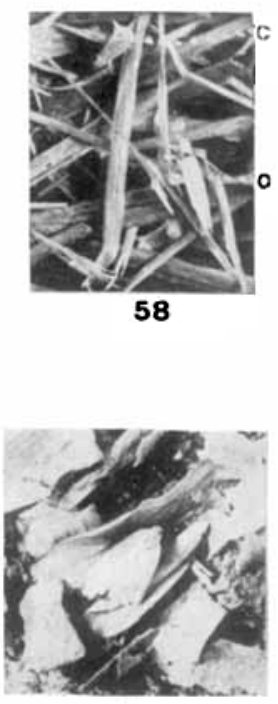

61 